Hydrol. Earth Syst. Sci., 15, 2007-2024, 2011

www.hydrol-earth-syst-sci.net/15/2007/2011/

doi:10.5194/hess-15-2007-2011

(C) Author(s) 2011. CC Attribution 3.0 License.

\title{
On the value of combined event runoff and tracer analysis to improve understanding of catchment functioning in a data-scarce semi-arid area
}

\author{
M. Hrachowitz ${ }^{1}$, R. Bohte ${ }^{1}$, M. L. Mul ${ }^{2}$, T. A. Bogaard ${ }^{1,2}$, H. H. G. Savenije ${ }^{1,2}$, and S. Uhlenbrook ${ }^{2,1}$ \\ ${ }^{1}$ Water Resources Section, Faculty of Civil Engineering and Applied Geosciences, Delft University of Technology, \\ Stevinweg 1, 2600 GA Delft, The Netherlands \\ ${ }^{2}$ UNESCO-IHE Institute for Water Education, Westvest 7, 2601 DA Delft, The Netherlands
}

Received: 2 February 2010 - Published in Hydrol. Earth Syst. Sci. Discuss.: 16 February 2010

Revised: 31 May 2011 - Accepted: 14 June 2011 - Published: 27 June 2011

\begin{abstract}
Hydrological processes in small catchments are not quite understood yet, which is true in particular for catchments in data scarce, semi-arid regions. This is in contrast with the need for a better understanding of water fluxes and the interactions between surface- and groundwater in order to facilitate sustainable water resources management in such environments, where both floods and droughts can result in severe crop loss. In this study, event runoff coefficient analysis and limited tracer data of four small, nested sub-catchments $\left(0.4-25.3 \mathrm{~km}^{2}\right)$ in a data scarce, semi-arid region of Tanzania helped to characterize the distinct response of the study catchments and to gain insights into the dominant runoff processes. The estimated event runoff coefficients were very low and did not exceed 0.09. They were found to be significantly related to the 5-day antecedent precipitation totals as well as to base flow, indicating a close relation to changes in soil moisture and thus potential switches in runoff generation processes. The time scales of the "direct flow" reservoirs, used to compute the event runoff coefficients, were up to one order of magnitude reduced for extreme events, compared to "average" events, suggesting the activation of at least a third flow component, besides base- and direct flow, assumed to be infiltration overland flow. Analysis of multiple tracers highlighted the importance of pre-event water to total runoff, even during intense and
\end{abstract}

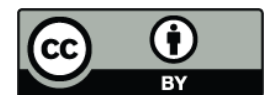

Correspondence to: M. Hrachowitz (m.hrachowitz@tudelft.nl) high yield precipitation events. It further illustrated the distinct nature of the catchments, in particular with respect to the available water storage, which was suggested by different degrees of tracer damping in the individual streams. The use of multiple tracers subsequently allowed estimating uncertainties in hydrograph separations arising from the use of different tracers. The results highlight the presence of considerable uncertainties, emphasizing the need for multiple tracers in order to avoid misleading results. This study shows the value of hydrological data collection over one whole wet season using multi-tracers to improve the understanding of hydrological functioning and thus for water resources management in data scarce, semi-arid environments.

\section{Introduction}

A solid understanding of the hydrological processes in a catchment is important in order to guarantee appropriate management of the available surface water and groundwater resources, both in terms of quality and quantity. In semi-arid populated environments in sub-Saharan Africa (SSA), this is probably even more essential than in other regions since both floods and droughts can result in severe crop loss (e.g. Mul, 2009; Rockström et al., 2004). A good understanding of the hydrology of a semi-arid catchment can help to increase the productivity in smallholder farms and to sustain long-term food security. In order to achieve this, insights in

Published by Copernicus Publications on behalf of the European Geosciences Union. 
the behaviour of the water fluxes and the interaction between groundwater and surface water is of utmost importance. This includes the quantification of the spatial-temporal variability of the water fluxes and responses to extreme climatic conditions. Much experimental work on understanding hydrological processes has been done in temperate, humid climates using either single or multi-method approaches (e.g. Uchida et al., 2005; Blume et al., 2008; Uhlenbrook et al., 2002, 2008). However, experimental hydrology and processrelevant studies in the predominantly data scarce semi-arid regions of SSA or Central Asia are, due to mostly logistical and financial constraints, less widespread (e.g. Sandström, 1996; McCartney et al., 1998; Kongo et al., 2007; Wenninger et al., 2008; Mul et al., 2009, Love et al., 2010; Makurira et al., 2010), thus limiting our understanding of catchment scale hydrological functioning and, maybe more importantly, thereby inhibiting sustainable water resources strategies and policies in such data scarce areas.

One commonly used, simple, but very effective tool to gain insights into catchment processes is event runoff coefficient analysis (e.g. Merz et al., 2006), which can provide information on discharge dynamics and moisture storage characteristics of a catchment. While, for example Capell et al. (2011) found mean annual runoff coefficients of up to 0.58 for several humid catchments (cf. Ponce et al., 2000) in a cool region with aridity index $I_{\mathrm{A}}=E_{\mathrm{p}} / P$ (Budyko, 1974) of approximately $0.5, \mathrm{Li}$ et al. (2011), reported mean annual runoff coefficients $\left(C_{\mathrm{E}}\right)$ of 0.19 and 0.27 for two sub-humid catchments with $I_{\mathrm{A}} \sim 1$. The systematically higher event runoff coefficients in the wet season $\left(C_{\mathrm{E}} \leq 0.80\right)$ than in the dry season $\left(C_{\mathrm{E}} \leq 0.20\right)$ were shown to be closely linked to changes in soil moisture and eventually to switches in runoff generation processes. Wenninger et al. (2008), on the other hand, highlighted the importance of base flow in a semi-arid catchment $\left(I_{\mathrm{A}} \sim 2\right)$, where event runoff coefficients ranged between 0.01 (dry season) and 0.12 (wet season).

Likewise, tracer-based analysis of catchment behaviour, such as geographic and temporal hydrograph separation (e.g. Christophersen et al., 1990; Uhlenbrook et al., 2002; Dunn et al., 2006; Laudon et al., 2007; Hrachowitz et al., 2009), analysis of catchment transit time distributions (e.g. McGuire et al., 2005; Hrachowitz et al., 2010a; Lyon et al., 2010) as well as interpretations of the spatio-temporal evolution of tracer concentrations in soils and streams (e.g. Soulsby et al., 2007; Anderson et al., 2009; Rouxel et al., 2011; Birkel et al., 2011), are key to meaningfully characterize and conceptualize catchment internal processes (e.g. Weiler et al., 2003; Soulsby et al., 2009). However, such studies are frequently based on single-tracer analysis, not exploring the potentially considerable uncertainties (cf. Rice and Hornberger, 1998) arising when using multiple tracers to determine specific runoff components.

The objective of this paper is thus (1) to evaluate the use of limited hydrometric and tracer data to characterize and compare the hydrological functioning of four nested, small scale catchments in a semi-arid, data scarce region over an entire wet season, and (2) to show the added value of using short term multiple tracer data rather than single-tracer data to better represent uncertainties in runoff component estimates in such a data scarce region.

\section{Study site}

The study area was located within the $300 \mathrm{~km}^{2}$ Makanya catchment (Mul et al., 2006) in the South Pare Mountains in Northern Tanzania (Fig. 1). The region has a population of approximately 35000 , living in small villages and mainly living from small scale subsistence agriculture. The study sites comprised 4 nested sub catchments, Mataini $\left(0.3 \mathrm{~km}^{2}\right)$, Ndolwa $\left(8.8 \mathrm{~km}^{2}\right)$, Vudee $\left(14.6 \mathrm{~km}^{2}\right)$ and Bangalala $\left(25.3 \mathrm{~km}^{2}\right)$ at elevations between 700 to $2400 \mathrm{~m}$ with the main outlet at $37^{\circ} 52^{\prime} \mathrm{E}, 4^{\circ} 14^{\prime} \mathrm{S}$. The climate is characterized by two wet seasons, locally known as the Vuli (OctoberDecember) and Masika (March-May) seasons and in the following referred to as wet season 1 (WS1) and wet season 2 (WS2). While total annual rainfall averages range between approximately $550 \mathrm{~mm} \mathrm{a}^{-1}$ in the lower regions and $800 \mathrm{~mm} \mathrm{a}^{-1}$ in the higher regions, average potential evaporation reaches about $2000 \mathrm{~mm} \mathrm{a}^{-1}$. The underlying geology is characterized by superficial deposits and metamorphic, igneous rocks, associated with the granulite-gneiss complexes of the Mozambique belt (Bagnall, 1963).

The Mataini sub-catchment, a head water catchment draining into the Vudee catchment, is characterized by forest and a flat and swampy source area surrounded by small farm plots used for growing maize, with limited soil and water conservation measures, which is prone to erosion. Further downstream the stream turns into steeper sections with abundant rock outcrops and large trees rooting in the riparian zone. This part is characterised by loamy - silty soils ( $<2 \mathrm{~m}$ depth) on top of a weathered rock base (Kessler, 2008). Both, the Ndolwa and Vudee sub-catchments drain into the Bangalala catchment. They are characterized by steep slopes, shallow soils ( $<2 \mathrm{~m}$ depth) and numerous rock outcrops. At specific locations, water is held back by the rock outcrop, creating marshlands (Mul et al., 2007). Furthermore, both catchments are mainly cultivated agricultural land with sparse terraces, thus being subject to extensive erosion. Some parts are still forested, either with old-growth or second-growth forest, replanted at the beginning of the 20th century.

\section{Data and methods}

\subsection{Hydrometric and tracer data}

Precipitation amounts were automatically recorded by four ground level tipping bucket rain gauges (Campbell Scientific, TE525WS, resolution $\pm 0.1 \mathrm{~mm}$ ) in and close to the 

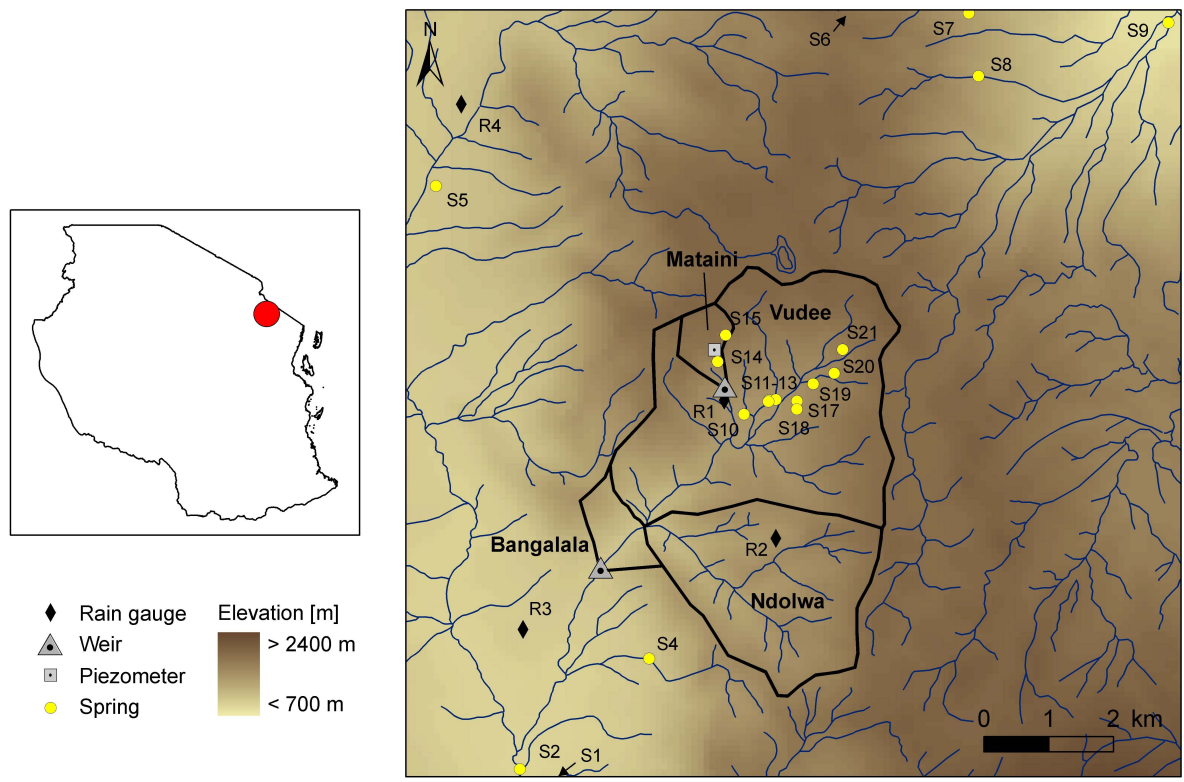

Fig. 1. Context and elevation maps of the 4 nested study catchments Mataini $\left(0.3 \mathrm{~km}^{2}\right)$, Ndolwa $\left(8.8 \mathrm{~km}^{2}\right)$, Vudee $\left(14.6 \mathrm{~km}{ }^{2}\right)$ and Bangalala $\left(25.3 \mathrm{~km}^{2}\right)$.

study catchments (R1-R4; Fig. 1). Average catchment precipitation was estimated with Thiessen polygons. The average catchment precipitation during the study year was with $923 \mathrm{~mm} \mathrm{a}^{-1}$ (1 October 2007-1 October 2008) considerably above the long-term annual catchment precipitation of $\sim 750 \mathrm{~mm} \mathrm{a}^{-1}$.

Hourly runoff at the outlets of the small, forested Mataini sub-catchment and the Bangalala catchment, approximately $1 \mathrm{~km}$ downstream of the Vudee/Ndolwa confluence (Fig. 1) was obtained from 15-min interval measurements at concrete weirs. The rating curves were cross-calibrated with salt dilution experiments at several occasions. An extreme rain event in December 2007, resulting in a large flood, caused considerable damage throughout the catchments. Both V-notches weirs were destroyed, thus interrupting the runoff monitoring between December 2007 and March (Mataini)/April (Bangalala) 2008. The available observation periods are shown in Fig. $2 \mathrm{a}$ and $\mathrm{b}$.

To analyze for isotopic composition of precipitation and in the absence of automatic samplers, local people manually took precipitation samples after reading a rainfall depth larger than $10 \mathrm{~mm}$ over the previous $24 \mathrm{~h}$ at the rain gauge sites. During two rain events in WS1 additional rainwater samples were obtained from several locations in and close to the Bangalala catchment (20 November 2007: 5 locations and 12 December 2007: 8 locations; not shown).

Likewise, local people living close to the sampling points, i.e. outlets of the study catchments were employed to manually take stream water samples using plastic bottles during both, low flows and events. Daily sampling (09:00 a.m., UTC+3) between 18 November 2007 and 8 December 2007,
9 April 2008 and 13 May 2008 (Vudee, Ndolwa, Bangalala) as well as between 13 March 2008 and 24 April 2008 (Mataini) ensured the availability of low flow, i.e. pre-event, samples in case of events during the respective days. Event stream water samples with an interval of approximately 1 to $2 \mathrm{~h}$ were available between 18 November 2007 and 1 December 2007, 28-29 April 2008 (Vudee, Ndolwa, Bangalala) as well as 26-28 March 2008 (Mataini).

21 groundwater springs, in or close to the study catchments (Fig. 1) were sampled in order to characterize the spatial variability and seasonal dynamics of spring water and thus groundwater quality. Most springs were sampled 3 times: at the beginning of WS1 (Vuli, October 2007), at the end of WS1 (Vuli, December 2007) and during WS2 (Masika, April 2008).

Furthermore a piezometer was installed in the upper part of the Mataini catchment, close to springs S14 and S15 (Fig. 1). From this piezometer groundwater level was first measured manually twice daily (13 March 200829 April 2008) and then automatically at hourly intervals (30 April 2008-1 June 2008)

Temperature, $\mathrm{pH}$ and EC have been measured in-situ for all stream- and groundwater samples (WTW 3400i). The probe was calibrated before and after each event in the laboratory. For further analysis, all samples were filtered using $0.45 \mu \mathrm{m}$ nitrocellulose filters and stored in glass vials. Both, stream- and groundwater samples, were subsequently analyzed for dissolved silica $\left(\mathrm{SiO}_{2}\right)$ using the spectrophotometric Silicomolybdate method with an instrument precision of $1.0 \mathrm{mg} \mathrm{l}^{-1}$ (standard deviation). Additionally, using digital Hach titration field kits, groundwater samples were analyzed 
a) Mataini

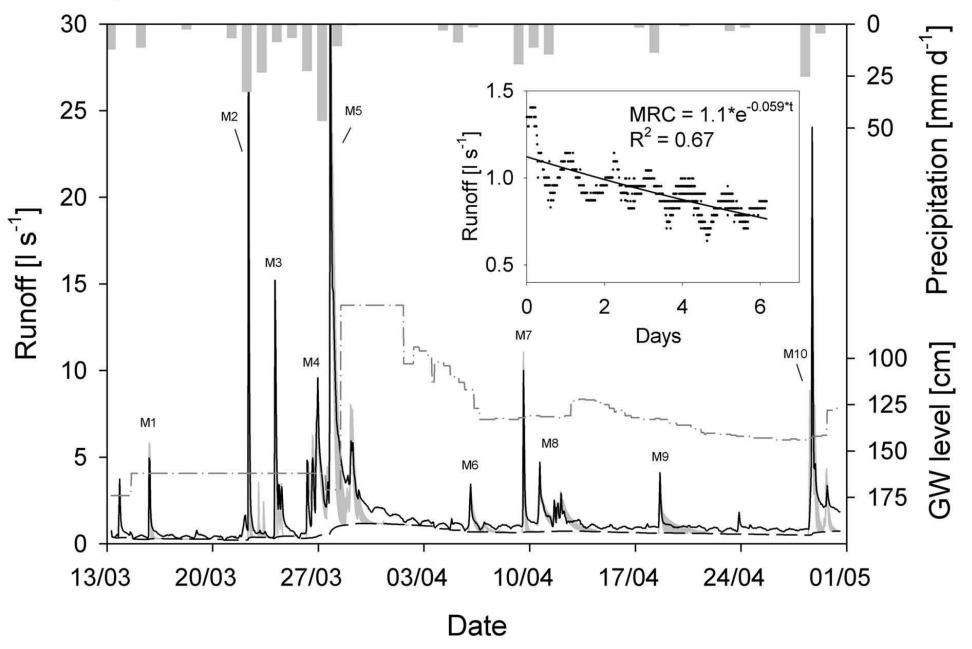

b) Bangalala

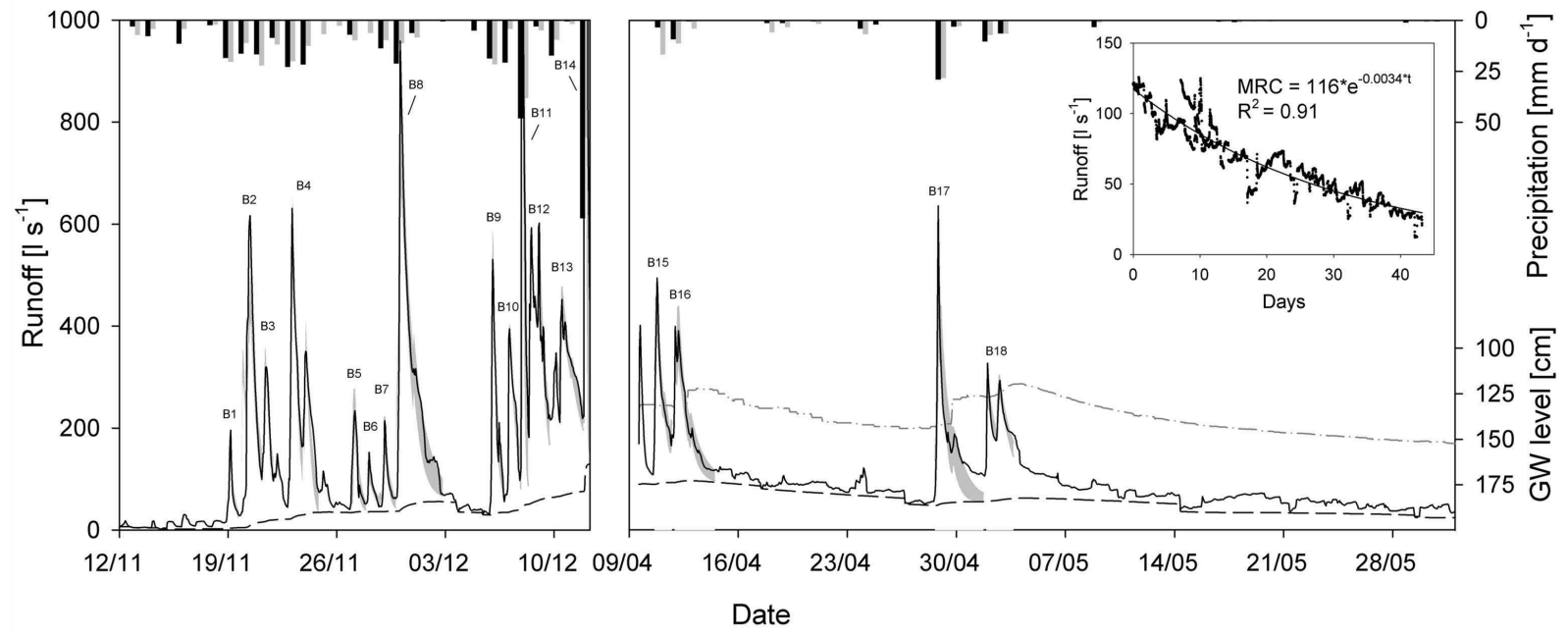

Fig. 2. Observed times series of precipitation, stream flow (-) and groundwater level (-.-), as well as the modeled time series for baseflow (-) and the modeled $95 \%$ uncertainty interval of direct flow (grey shaded area) for (a) the Mataini catchment and (b) the Bangalala catchment. M1-M10 and B1-B18 denote the defined precipitation and runoff events in Mataini and Bangalala, respectively.

for $\mathrm{Ca}^{2+}, \mathrm{Mg}^{2+}$ (EDTA) and $\mathrm{HCO}_{3}^{-}\left(\mathrm{H}_{2} \mathrm{SO}_{4}\right)$, with a precision of $1 \%$. All samples were analyzed within 2 days after sampling.

The deuterium $\left({ }^{2} \mathrm{H} /{ }^{1} \mathrm{H}\right)$ and oxygen-18 $\left({ }^{18} \mathrm{O} /{ }^{16} \mathrm{O}\right)$ ratios of the water samples were simultaneously determined with a liquid water isotope analyzer (Los Gatos Research, model 908-0008) in combination with a CTC LC-PAL liquid autosampler, using a standard analytical protocol (cf. Lis et al., 2008; Birkel et al., 2010). Data were transformed into $\delta$ notion $\left(\delta^{2} \mathrm{H}\right.$ and $\delta^{18} \mathrm{O}$ in \%o ) according to Vienna Standard Mean Ocean Water (VSMOW) standards. An average instrument precision of 0.21 for $\delta^{18} \mathrm{O}$ and $0.63 \%$ ofor $\delta^{2} \mathrm{H}$ was reached and post-processing was performed according to the IAEA standard (Newman et al., 2009).

\subsection{Event runoff coefficients}

Event runoff coefficients $\left(C_{\mathrm{E}}\right)$ directly link precipitation events $\left(P_{\mathrm{E}}\right)$ with direct or rapid flow components during these events $\left(Q_{\mathrm{DE}}\right)$ so that $C_{\mathrm{E}}=Q_{\mathrm{DE}} / P_{\mathrm{E}}$. Direct event runoff $Q_{\mathrm{DE}}$ represents the amount of precipitation that immediately contributes to runoff during an event, while slower baseflow components are subject to considerable lags in the response. It was thus, as a first step, necessary to separate baseflow from direct runoff, which was done using a digital filter as proposed by Chapman and Maxwell (1996) and previously successfully applied (e.g. Merz et al., 2006; Li et al., 2011): 
$Q_{\mathrm{B}}(t)=\frac{a_{\mathrm{B}}}{2-a_{\mathrm{B}}} Q_{\mathrm{B}}(t-\Delta t)+\frac{1-a_{\mathrm{B}}}{2-a_{\mathrm{B}}} Q_{\mathrm{T}}(t), \quad Q_{\mathrm{B}}(t) \leq Q_{\mathrm{T}}(t)$

$a_{\mathrm{B}}=e^{-k_{\mathrm{B}} \Delta t}$

$Q_{\mathrm{DE}}(t)=Q_{\mathrm{T}}(t)-Q_{\mathrm{B}}(t)$

where $Q_{\mathrm{B}}(t), Q_{\mathrm{DE}}(t)$ and $Q_{\mathrm{T}}(t)$ are baseflow, direct and total runoff at time $t, \Delta t$ is the observation time step $(1 \mathrm{~h})$ and $a_{\mathrm{B}}$ is the baseflow recession constant, derived from the baseflow storage coefficient $k_{\mathrm{B}}$. The baseflow storage coefficients $k_{\mathrm{B}}$ for the two gauging stations at Mataini and Bangalala were estimated from Master Recession Curves (MRC), using the automated matching-strip method suggested by Lamb and Beven (1997). Briefly, the method is based on recession periods longer than specified thresholds ( $48 \mathrm{~h}$ in this study), which are combined into one synthetic recession curve, in which the individual recession segments are sorted in ascending order based on the tail-end discharge values. Starting from the segment with the lowest tail-end value, which is shifted in time until it overlaps with the following segment, the concatenation continues until all segments are incorporated in the MRC (cf. Fenicia et al., 2006).

In this study precipitation events were defined as periods of continuous precipitation, yielding at least $2.5 \mathrm{~mm} \mathrm{~d}^{-1}$ mean catchment precipitation and interrupted only by dry spells of no longer than $6 \mathrm{~h}$. Runoff events were defined from the beginning of the rising limb of the hydrograph after the beginning of an event until $72 \mathrm{~h}$ after the end of the event or until the beginning of the next event. A total of 10 (M1-M10) and 18 events (B1-B18) were identified for the Mataini and Bangalala catchments, respectively (Fig. 2, Tables 1 and 2).

Following Merz et al. (2006) and assuming that direct runoff is generated in a storage element that drains linearly, the individual event runoff coefficients were then computed from a simple linear reservoir models with storage coefficients $k_{\mathrm{DE}}$ and event runoff coefficients $C_{\mathrm{E}}$. For each event separately both model parameters $k_{\mathrm{DE}}$ and $C_{\mathrm{E}}$ were calibrated to optimize the model performance according to the Nash-Sutcliffe efficiency (NSE; Nash and Sutcliffe, 1970) using Monte-Carlo (MC) sampling. In $10000 \mathrm{MC}$ realizations the two parameters were randomly drawn from uniformed prior distributions $\left(0<k_{\mathrm{DE}} \leq 75 \mathrm{~d}^{-1} ; 0<C_{\mathrm{E}} \leq 1\right)$. Note, that although storage coefficient $k_{\mathrm{DE}}$ should be implicitly constant for a given catchment, the value was allowed to change in order to compensate violations of the linear reservoir assumptions and to allow for the influence of possible further direct runoff components, such as overland flow. Thus, $k_{\mathrm{DE}}$ was defined as an event storage coefficient.

Uncertainty in parameter and runoff estimates was estimated using the Generalized Likelihood Uncertainty Estimation (GLUE; Beven and Binley, 1992). GLUE is based on the rejection of an optimal parameter set in favour of a range of "equally" good parameter sets (Freer et al., 1996). The uncertainty bounds using likelihood weights $L$, rescaled to give a cumulative sum of 1 , were defined as:

$P\left(\hat{Y}_{t}<y_{t}\right)=\sum_{j=1}^{N} L\left(\theta_{i} \mid \hat{Y}_{t}<y_{t}\right)$

$L\left(\theta_{i} \mid Y\right)=\mathrm{NSE}^{W}$

where $P$ is the prediction quantile for $Y$ (the value of variable $Y$ at time $t$, estimated by model $\theta_{i}$ ) being less than $y, N$ is the number of retained, behavioural models and exponent $W$, accentuating the weight for better simulations. Thus relatively high values of $W$, which strongly penalize poor model performances, reduce subjectivity introduced by the choice of threshold values for behavioural models. Although the width of the uncertainty interval is affected by the choice of $W$, it rapidly converges towards quasi-constant values as $W$ increases. Furthermore, the use of high values for $W$ eliminates subjectivity in choosing a threshold of model performance which defines behavioural models, as with high values of $W$ the sensitivity of the uncertainty intervals to the chosen performance threshold becomes negligible. Thus, in this study all models with NSE $\geq 0$ were retained as "behavioural" and used to construct the likelihood-weighted $95 \%$ uncertainty bounds ( $\mathrm{UI}_{95 L}$ ) with an exponent $W=30$ (cf. Freer et al., 1996). Both parameters of the event runoff coefficient analysis, $k_{\mathrm{DE}}$ and $C_{\mathrm{E}}$ were subsequently related to several metrics of catchment wetness, including event precipitation totals, event precipitation intensities and antecedent precipitation totals of the 5, 10 and 15 preceding days $\left(\mathrm{AP}_{5}, \mathrm{AP}_{10}\right.$, $\mathrm{AP}_{15}$ ) using covariances, weighted according to the respective NSE (cf. Hrachowitz et al., 2010b):

$\operatorname{cov}(x, y, w)=\frac{\sum_{i=1}^{N} w_{i}\left(x_{i}-m(x, w)\right)\left(y_{i}-m(y, w)\right)}{\sum_{i=1}^{N} w_{i}}$

where $N$ is the sample size, $x$ and $y$ are the data vectors, $w$ is the weight, here assumed to be the NSE and $m$ is the weighted mean:

$m(x, w)=\frac{\sum_{i=1}^{N} w_{i} x_{i}}{\sum_{i=1}^{N} w_{i}}, m(y, w)=\frac{\sum_{i=1}^{N} w_{i} y_{i}}{\sum_{i=1}^{N} w_{i}}$.

\subsection{Hydrograph Separation}

Stream flow can be, using geochemical or isotopic tracers, separated into two or more runoff components, if these show distinct tracer signatures (e.g. Christopherson et al., 1990; Buttle and Peters, 1997; Soulsby et al., 2003), according to: 
Table 1. Event summaries for the Mataini catchment (M1-M10). $\mathrm{AP}_{5}$ represents the total precipitation of the preceding 5 days, $k_{\mathrm{DE}}$ is the event storage coefficient and $\mathrm{RC}_{\mathrm{E}}$ is the event runoff coefficient. The values in the brackets show the $95 \%$ uncertainty interval.

\begin{tabular}{|c|c|c|c|c|c|c|c|c|c|c|}
\hline \multirow{2}{*}{$\begin{array}{r}\text { Event } \\
\text { number }\end{array}$} & \multirow{2}{*}{$\begin{array}{l}\text { Event } \\
\text { start }\end{array}$} & \multirow{2}{*}{$\begin{array}{l}\text { Areal event } \\
\text { precipitation }\end{array}$} & \multirow{2}{*}{ Duration } & \multicolumn{2}{|c|}{ Event precipitation intensity } & \multirow{2}{*}{$\mathrm{AP}_{5}$} & \multirow{2}{*}{$\begin{array}{l}\text { Peak } \\
\text { runoff }\end{array}$} & \multirow{2}{*}{$k_{\mathrm{DE}}$} & \multirow{2}{*}{$C_{\mathrm{E}}$} & \multirow{2}{*}{ NSE } \\
\hline & & & & $\max$ & mean & & & & & \\
\hline & & $(\mathrm{mm})$ & (h) & $\left(\mathrm{mm} \mathrm{h}^{-1}\right)$ & $\left(\mathrm{mm} \mathrm{h}^{-1}\right)$ & $(\mathrm{mm})$ & $\left(1 s^{-1}\right)$ & $\left(d^{-1}\right)$ & $(\%)$ & $(-)$ \\
\hline M1 & $15 / 03 / 08$ & 11.3 & 3 & 6.6 & 3.8 & 12.0 & 5.3 & $21.2(11.9-45.1)$ & $1.4(1.0-1.7)$ & 0.91 \\
\hline M2 & $22 / 03 / 08$ & 30.9 & 3 & 26.3 & 10.3 & 9.5 & 26.7 & $41.5(22.8-73.1)$ & $2.2(1.6-2.9)$ & 0.99 \\
\hline M3 & $24 / 03 / 08$ & 30.6 & 13 & 10.7 & 2.4 & 41.0 & 16.5 & $19.6(12.1-53.1)$ & $2.4(1.7-2.9)$ & 0.94 \\
\hline M4 & $26 / 03 / 08$ & 34.9 & 35 & 6.6 & 1.0 & 71.6 & 9.8 & $3.0(2.1-4.3)$ & $4.9(4.2-5.6)$ & 0.69 \\
\hline M5 & $27 / 03 / 08$ & 51.8 & 37 & 16.9 & 1.4 & 68.8 & 56.2 & $5.2(3.1-10.3)$ & $5.9(4.3-7.4)$ & 0.83 \\
\hline M6 & 05/04/08 & 8.7 & 4 & 3.0 & 2.2 & 3.2 & 4.1 & $4.8(3.1-7.2)$ & $2.2(1.8-2.8)$ & 0.72 \\
\hline M7 & $09 / 04 / 08$ & 19.4 & 4 & 11.2 & 4.9 & 13.8 & 10.7 & $17.2(10.7-34.3)$ & $1.5(1.1-1.9)$ & 0.90 \\
\hline M8 & $10 / 04 / 08$ & 25.9 & 42 & 5.1 & 0.6 & 30.2 & 5.3 & $1.7(1.2-3.0)$ & $2.7(2.3-3.2)$ & 0.75 \\
\hline M9 & $18 / 04 / 08$ & 13.8 & 3 & 5.7 & 4.6 & 1.7 & 4.6 & $0.9(0.8-13.9)$ & $0.9(0.3-1.6)$ & 0.57 \\
\hline M10 & $28 / 04 / 08$ & 25.1 & 10 & 11.2 & 2.5 & 5.0 & 23.9 & $10.6(6.4-19.6)$ & $4.0(3.0-5.0)$ & 0.79 \\
\hline
\end{tabular}

$Q_{\mathrm{T}}=Q_{1}+Q_{2}+\ldots+Q_{n}$

$c_{T}^{\mathrm{tr}_{i}} Q_{\mathrm{T}}=c_{1}^{\mathrm{tr}_{i}} Q_{1}+c_{2}^{\mathrm{tr}_{i}} Q_{2}+\ldots+c_{n}^{\mathrm{tr}_{i}} Q_{n}$

where $Q_{\mathrm{T}}$ is the total runoff, $Q_{1}, Q_{2}, \ldots, Q_{n}$ are the runoff components or end-members and $c_{1}^{\mathrm{tr}}, c_{2}^{\mathrm{tr}}$ and $c_{n}^{\mathrm{tr}}$ are the respective concentrations of one observed tracer. Separating runoff into $\mathrm{n}$ different component thus requires $\mathrm{n}-1$ tracers to solve the linear mixing equations. Several assumptions have to be met in order to meaningfully apply the method. These include (a) the significant difference in tracer concentrations in the different components, (b) time and space invariance of the tracers, (c) negligible contributions of additional components, (d) conservative and well mixing and (e) the absence of collinearity in tracer concentrations of the individual components. For detailed a discussion of the assumptions the reader is referred to Sklash and Farvolden (1979), Buttle (1994), Durand and Torres (1996) as well as Hoeg et al. (2000).

In this study each component's contribution to runoff was estimated using several tracers. Based on the observed tracers, which were assumed to be normally distributed around their observed value $\mu$ with measurement precision $\sigma$, the distributions of the individual runoff component contributions were estimated. This was done by randomly drawing 10000 samples from the individual measurement error distributions and by correspondingly using these samples in Eqs. (8) and (9). The distributions of each component's runoff contributions for the individual tracers were then combined into one distribution and rescaled to unity. The combined component runoff contributions for each sample were then characterized by the median as central estimate as well as the $95 \%$ inter-quantile range, i.e. the sample $95 \%$ uncertainty interval $\left(\mathrm{UI}_{95 s}\right.$ ) of these combined runoff contribution distributions. In order to facilitate continuous prediction of the individual components' runoff contributions between the actual sampling points, the combined runoff contribution distributions of each sample were once more randomly sampled 10000 times. Each sampled combined sample runoff contribution for each of the 10000 realizations, was then related to total runoff. This regression analysis subsequently allowed obtaining combined continuous multi-tracer central estimates, dependent on total runoff, and the corresponding $95 \%$ inter-quantile ranges, i.e. the continuous $95 \%$ uncertainty intervals $\left(\mathrm{UI}_{95}\right.$ ) of each component's contribution to total runoff (cf. Hrachowitz et al., 2010c), allowing to predict each component's contribution at unsampled instants during individual runoff events. Here, the individual components to total runoff are event and pre-event water, used in the Mataini and Banagala catchments, as well as the geographical origin of water: the Vudee and Ndolwa catchments' contribution to total runoff at the Bangala weir. Note that the uncertainty estimation was not done analytically as suggested by Genereux (1998), because the combined multi-tracer runoff contribution distributions were multi-modal and thus nonnormal.

\section{Results and discussion}

\subsection{End-members}

The spatio-temporal variability of geochemical and isotopic end-member compositions holds valuable information about catchment processes. The isotopic composition, i.e. $\delta D$ and $\delta^{18} \mathrm{O}$, of 36 rain samples from Vudee (R1) and Mwembe (R4) as well as 10 springs water samples (S10-S21), taken in the period from October 2007 to April 2008 is shown in Fig. 3. The Local Meteoric Water Line (LMWL, $\delta D=$ $7.86 \delta^{18} \mathrm{O}+11.1 \%$ VSMOW) coincides well with the Global Meteoric Water Line (GMWL, $\delta D=8.13 \delta^{18} \mathrm{O}+10.8 \%$ o VSMOW; Clark and Fritz, 1997). The weighted mean 
Table 2. Event summaries for the Bangalala catchment (B1-B18). Event precipitation is the average catchment precipitation, the values in brackets show the event precipitation in the Vudee and Ndolwa sub-catchments. $\mathrm{AP}_{5}$ represents the total precipitation of the preceding 5 days, $k_{\mathrm{DE}}$ is the event storage coefficient and $\mathrm{RC}_{\mathrm{E}}$ is the event runoff coefficient. The values in the brackets show the $95 \%$ uncertainty interval. Values of peak runoff measured at Bangalala weir.

\begin{tabular}{|c|c|c|c|c|c|c|c|c|c|c|c|c|c|}
\hline & \multirow{2}{*}{$\begin{array}{r}\text { Event } \\
\text { number }\end{array}$} & \multirow{2}{*}{$\begin{array}{r}\text { Event } \\
\text { start }\end{array}$} & \multirow{2}{*}{$\begin{array}{l}\text { Areal event } \\
\text { precipitation }\end{array}$} & \multirow[t]{2}{*}{ Duration } & \multicolumn{2}{|c|}{$\begin{array}{l}\text { Event precipitation } \\
\text { intensity }\end{array}$} & \multirow[t]{2}{*}{$\mathrm{AP}_{5}$} & \multirow{2}{*}{$\begin{array}{r}\text { Peak } \\
\text { runoff }\end{array}$} & \multirow[t]{2}{*}{$k_{\mathrm{DE}}$} & \multirow[t]{2}{*}{$C_{\mathrm{E}}$} & \multirow[t]{2}{*}{ NSE } & \multicolumn{2}{|c|}{$\begin{array}{c}\text { Runoff } \\
\text { contribution }\end{array}$} \\
\hline & & & & & $\max$ & mean & & & & & & Vudee & Ndolwa \\
\hline & & & $(\mathrm{mm})$ & (h) & $\left(\mathrm{mm} \mathrm{h}^{-1}\right)$ & $\left(\mathrm{mm} \mathrm{h}^{-1}\right)$ & $(\mathrm{mm})$ & $\left(\mathrm{l} \mathrm{s}^{-1}\right)$ & $\left(\mathrm{d}^{-1}\right)$ & $(\%)$ & $(-)$ & $(-)$ & $(-)$ \\
\hline \multirow{14}{*}{ 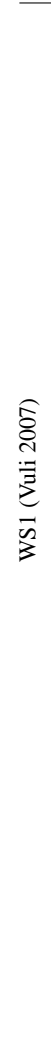 } & B1 & $19 / 11 / 07$ & $\begin{array}{l}22.7 \\
(23.8 / 20.2)\end{array}$ & 4 & 15.6 & 5.7 & 11.0 & 200 & $\begin{array}{l}3.6 \\
(2.7-4.9)\end{array}$ & $\begin{array}{l}0.8 \\
(0.7-0.9)\end{array}$ & 0.69 & $\begin{array}{l}0.66 \\
(0.47-0.71)\end{array}$ & $\begin{array}{l}0.34 \\
(0.29-0.53)\end{array}$ \\
\hline & B2 & $20 / 11 / 07$ & $\begin{array}{l}29.8 \\
(27.1 / 32.5)\end{array}$ & 14 & 6.8 & 2.0 & 34.0 & 620 & $\begin{array}{l}2.0 \\
(1.6-2.9)\end{array}$ & $\begin{array}{l}4.0 \\
(3.5-4.4)\end{array}$ & 0.65 & $\begin{array}{l}0.52 \\
(0.36-0.70)\end{array}$ & $\begin{array}{l}0.48 \\
(0.30-0.64)\end{array}$ \\
\hline & B3 & $21 / 11 / 07$ & $\begin{array}{l}8.1 \\
(6.7 / 9.4)\end{array}$ & 4 & 4.8 & 2.0 & 55.5 & 320 & $\begin{array}{l}2.3 \\
(1.8-3.0)\end{array}$ & $\begin{array}{l}5.1 \\
(4.6-5.6)\end{array}$ & 0.86 & $\begin{array}{l}0.46 \\
(0.25-0.57)\end{array}$ & $\begin{array}{l}0.54 \\
(0.43-0.75)\end{array}$ \\
\hline & B4 & $23 / 11 / 07$ & $\begin{array}{l}38.3 \\
(44.8 / 32.5)\end{array}$ & 26 & 8.4 & 1.5 & 65.7 & 630 & $\begin{array}{l}2.5 \\
(1.8-3.3)\end{array}$ & $\begin{array}{l}3.7 \\
(3.2-4.3)\end{array}$ & 0.93 & $\begin{array}{l}0.49 \\
(0.39-0.65)\end{array}$ & $\begin{array}{l}0.51 \\
(0.35-0.61)\end{array}$ \\
\hline & B5 & $27 / 11 / 07$ & $\begin{array}{l}9.5 \\
(7.3 / 11.8)\end{array}$ & 5 & 3.2 & 1.9 & 46.0 & 230 & $\begin{array}{l}4.3 \\
(3.2-6.0)\end{array}$ & $\begin{array}{l}2.7 \\
(2.2-3.2)\end{array}$ & 0.89 & - & - \\
\hline & B6 & $28 / 11 / 07$ & $\begin{array}{l}2.1 \\
(0.0 / 4.2)\end{array}$ & 1 & 2.1 & 2.1 & 53.2 & 150 & $\begin{array}{l}2.0 \\
(1.4-2.6)\end{array}$ & $\begin{array}{l}4.1 \\
(2.5-5.5)\end{array}$ & 0.64 & - & - \\
\hline & B7 & $29 / 11 / 07$ & $\begin{array}{l}11.1 \\
(13.8 / 8.3)\end{array}$ & 3 & 8.4 & 3.7 & 23.7 & 210 & $\begin{array}{l}3.5 \\
(2.5-4.8)\end{array}$ & $\begin{array}{l}1.6 \\
(1.3-1.9)\end{array}$ & 0.94 & - & - \\
\hline & B8 & $30 / 11 / 07$ & $\begin{array}{l}22.0 \\
(26.6 / 17.4)\end{array}$ & 10 & 6.4 & 2.2 & 31.0 & 960 & $\begin{array}{l}1.4 \\
(1.0-2.1)\end{array}$ & $\begin{array}{l}8.6 \\
(6.6-9.5)\end{array}$ & 0.92 & $\begin{array}{l}0.42 \\
(0.29-0.59)\end{array}$ & $\begin{array}{l}0.58 \\
(0.41-0.71)\end{array}$ \\
\hline & B9 & 05/12/07 & $\begin{array}{l}20.3 \\
(18.9 / 21.7)\end{array}$ & 5 & 10.3 & 4.1 & 4.7 & 530 & $\begin{array}{l}4.1 \\
(2.9-5.8)\end{array}$ & $\begin{array}{l}2.6 \\
(2.1-3.2)\end{array}$ & 0.97 & - & - \\
\hline & B 10 & 06/12/07 & $\begin{array}{l}13.4 \\
(22.0 / 4.7)\end{array}$ & 5 & 5.3 & 2.7 & 23.3 & 390 & $\begin{array}{l}2.1 \\
(1.6-2.7)\end{array}$ & $\begin{array}{l}3.6 \\
(3.1-4.0)\end{array}$ & 0.81 & - & - \\
\hline & B11 & 08/12/07 & $\begin{array}{l}43.3 \\
(48.5 / 38.0)\end{array}$ & 6 & 25.2 & 7.2 & 36.6 & 2390 & $\begin{array}{l}9.1 \\
(6.2-13.9)\end{array}$ & $\begin{array}{l}2.8 \\
(2.2-3.3)\end{array}$ & 0.89 & - & - \\
\hline & B12 & $09 / 12 / 07$ & $\begin{array}{l}3.3 \\
(1.7 / 4.9)\end{array}$ & 3 & 2.9 & 1.1 & 79.5 & 600 & $\begin{array}{l}1.8 \\
(1.4-2.4)\end{array}$ & $\begin{array}{l}8.8 \\
(6.7-11.3)\end{array}$ & 0.91 & - & - \\
\hline & B13 & $10 / 12 / 07$ & $\begin{array}{l}13.6 \\
(17.5 / 9.8)\end{array}$ & 10 & 4.5 & 1.4 & 82.8 & 450 & $\begin{array}{l}0.9 \\
(0.5-1.0)\end{array}$ & $\begin{array}{l}7.7 \\
(6.8-8.4)\end{array}$ & 0.89 & - & - \\
\hline & B14 & $11 / 12 / 07$ & $\begin{array}{l}87.0 \\
(112.4 / 62.0)\end{array}$ & 6 & 46.4 & 14.5 & 75.0 & $\sim 19000$ & $\begin{array}{l}21.4 \\
(14.3-38.8)\end{array}$ & $\begin{array}{l}6.1 \\
(4.7-7.5)\end{array}$ & 0.83 & - & - \\
\hline \multirow{4}{*}{ 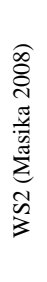 } & B15 & $10 / 04 / 08$ & $\begin{array}{l}11.9 \\
(7.0 / 16.6)\end{array}$ & 5 & 4.5 & 2.4 & 40.0 & 490 & $\begin{array}{l}2.2 \\
(1.6-2.8)\end{array}$ & $\begin{array}{l}6.4 \\
(4.9-6.9)\end{array}$ & 0.91 & - & - \\
\hline & B16 & $11 / 04 / 08$ & $\begin{array}{l}10.2 \\
(8.1 / 12.3)\end{array}$ & 13 & 4.3 & 0.8 & 51.0 & 400 & $\begin{array}{l}1.5 \\
(1.0-2.4)\end{array}$ & $\begin{array}{l}5.9 \\
(1.9-8.1)\end{array}$ & 0.98 & - & - \\
\hline & B17 & $28 / 04 / 08$ & $\begin{array}{l}27.0 \\
(26.9 / 27.4)\end{array}$ & 14 & 9.1 & 1.9 & 7.6 & 640 & $\begin{array}{l}1.7 \\
(1.1-2.9)\end{array}$ & $\begin{array}{l}3.5 \\
(2.8-4.1)\end{array}$ & 0.74 & $\begin{array}{l}0.37 \\
(0.27-0.48)\end{array}$ & $\begin{array}{l}0.63 \\
(0.52-0.73)\end{array}$ \\
\hline & B18 & 01/05/08 & $\begin{array}{l}17.1 \\
(20.6 / 13.5)\end{array}$ & 21 & 4.9 & 0.8 & 30.5 & 330 & $\begin{array}{l}1.0 \\
(0.7-1.2)\end{array}$ & $\begin{array}{l}6.9 \\
(5.8-7.4)\end{array}$ & 0.86 & - & - \\
\hline
\end{tabular}

values for $\delta D$ and $\delta^{18} \mathrm{O}$ for the two rain sampling locations over the entire period are $-14.7 \%$ and $-3.4 \%$, respectively. A clear clustering can be seen between the rains falling during the two wet seasons WS1 and WS2. WS1 (October-December 2007) is mainly characterized by isotopically enriched precipitation $\left(\delta D=-7.5 \% \circ\right.$ and $\delta^{18} \mathrm{O}=$ $-2.6 \%$ ), whereas the precipitation during WS2 (MarchMay 2008) was isotopically depleted $(\delta D=-26.4 \% \circ$ and $\delta^{18} \mathrm{O}=-4.7 \%$ ). In January and February, normally a short dry period, 3 rain events $>10 \mathrm{~mm}$ were sampled. Consistently, these rains plot at the edges of the two seasonal clusters (Fig. 3). The wet season clustering of the isotopic rain composition is most likely caused by the different origin of the rain during the two wet seasons. Nieuwolt (1973) and Sumner (1982) reported different prevailing wind directions during WS1 and WS2. While during WS1 a North-Easterly 
sea breeze from the Indian Ocean is predominant, SouthEasterly winds, parallel to the coastline dominate in WS2. When assuming that the moisture transport follows these prevailing wind directions, the moisture during WS1 season travels a significantly shorter distance over land than the moisture during WS2. As the travel distances of the moisture over land are closely linked to the continental rain out effect (Clark and Fritz, 1997), this results in isotopically lighter rains in WS2.

Rain water sampled at several locations during the 20 November 2007 and 12 December 2007 events showed the spatial variability in isotopic composition in and around the Bangalala catchment. During the 20 November 2007 event, the rainfall depth ranged from 7 to $20 \mathrm{~mm}$ for the different rain stations while during the 12 Decemebr 2007 event the variation was between 8 and $180 \mathrm{~mm}$. For both events a considerable spread in isotopic content $(-12 \leq \delta D \leq 5 \%$ o and $-3.2 \leq \delta^{18} \mathrm{O} \leq 0 \%$ ) between the different locations was observed.

Spring water samples (S1-S10) show a similarly strong seasonal clustering as the rain samples. However, while the WS1 (October-December 2007) samples plot close to the LMWL, samples from WS2 (April 2008) plot clearly below the LMWL, indicating $\delta^{18} \mathrm{O}$ enrichment relative to $\delta D$, caused by evaporation of recharge- and/or shallow groundwater. Figure 3 clearly shows the time lag of the "new" recharge to reach groundwater, which is more enriched in WS2 than in WS1, although precipitation shows the opposite pattern. In spite of the seasonal clustering, the seasonal variation of the isotopic groundwater composition is significantly damped, compared to the composition of the rain. Together with the lag in response this pattern indicates relatively long transit or turn-over times (Hrachowitz et al., 2009).

A Principal Component Analysis (PCA) on the geochemical and isotopic spring water composition (Fig. 4a), with an explained variance of $86 \%$ for PC1 and PC2, shows a similar pattern. While PC1 has high loadings for ion concentrations and elevation (as a proxy for location) PC2 is characterized by high loadings for isotopic composition and time elapsed since the beginning of WS1. The seasonal clustering of spring water isotopic composition is again evident. Compared to the seasonal variability, there is only relatively modest spatial variability of isotopic content in the springs in and around the Bangalala catchment. This is true in particular for samples from WS1 (October-December 2007), while samples from WS2 (April 2008) are spread over a wider range. This can be explained by the fact that during WS1 relatively well mixed, "old" groundwater, which damped spatial variability, played a more dominant role, since recharge had not yet fully set in and preferential flow-paths were not yet fully developed. This changed during WS2 when the soil moisture, groundwater table and thus the base flow contribution were highest (Fig. 2). The already wet soil matrix then facilitated rapid bypass flow of additional rain water through preferential flow pathways to the groundwater. This rapid translation of recharge potentially reduced the level of mixing and resulted in isotopic spring water signatures which more closely reflected the spatio-temporal variability of the rain water compositions at the individual spring locations.

In contrast to the isotopic spring water compositions, the geochemical, i.e. ionic, compositions of the spring water samples, characterized by PC1, showed a different pattern as no significant seasonal changes were detected (Fig. 4a). Note that increases in PC1 result mostly from additional but minor influences of isotopic compositions on PC1. The geochemical composition, however, reveals a distinct difference between water samples from different locations. Samples from the small $\left(0.3 \mathrm{~km}^{2}\right)$ Mataini headwater catchment (S14-15) exhibited the lowest ionic content. This is not only linked to the geological influence (Mul et al., 2007) but also to the limited storage capacity in the very shallow soil and to potentially short flow paths, which results in reduced water soil contact times and thus short water turn-over times (cf. Asano et al., 2002; Shamann et al., 2004). Spring water samples from the Vudee catchment (14.6 km²; S10-13, S17-19) showed a consistently higher ionic content, caused by larger local groundwater reservoirs further downstream (Mul et al., 2007) and thus longer contact and turn-over times. Springs downstream of the Bangalala weir (S1-4), where the topography is much more lowland in character, had significantly increased ionic concentrations. Together with the underlying geology, this indicates the emergence of a different groundwater regime, which is characterized by springs that occur when a geological fault cuts through an impermeable layer, forcing the deep ground water to the surface (Mul et al., 2007).

The ionic composition of water, which depends largely on the interaction of water with the soil matrix (cf. Uhlenbrook et al., 2002), was previously shown to behave nonconservatively. However, the timescales at which the tracer compositions, i.e. ion concentrations, of "new" soil- and recharge water converge toward the one in pre-existing soilor groundwater is, for many tracers, subject to conflicting results and an ongoing debate (e.g. Laudon and Slaymaker, 1997; Uhlenbrook et al., 2002; Asano et al., 2003; Pellerin et al., 2007). Thus, the geochemical composition, with its clear spatial pattern in the study area, was in the following rather used to separate the runoff contributions from different source areas, i.e. Vudee and Ndolwa, while the isotopic composition, where available, was used to separate the runoff into contributions from different flow components, i.e. event and pre-event water (except for Mataini, where both, isotopic and geochemical tracers were used in order to estimate the uncertainty caused by the use of different tracers). Note that due to the scatter in the respective spring water composition, the pre-event water end-member was assumed to be the composition of the preceding low flow period, which is a catchment integrated approximation. Furthermore it should be noted that, in absence of more detailed data, the volume weighted ionic composition of the total event precipitation 

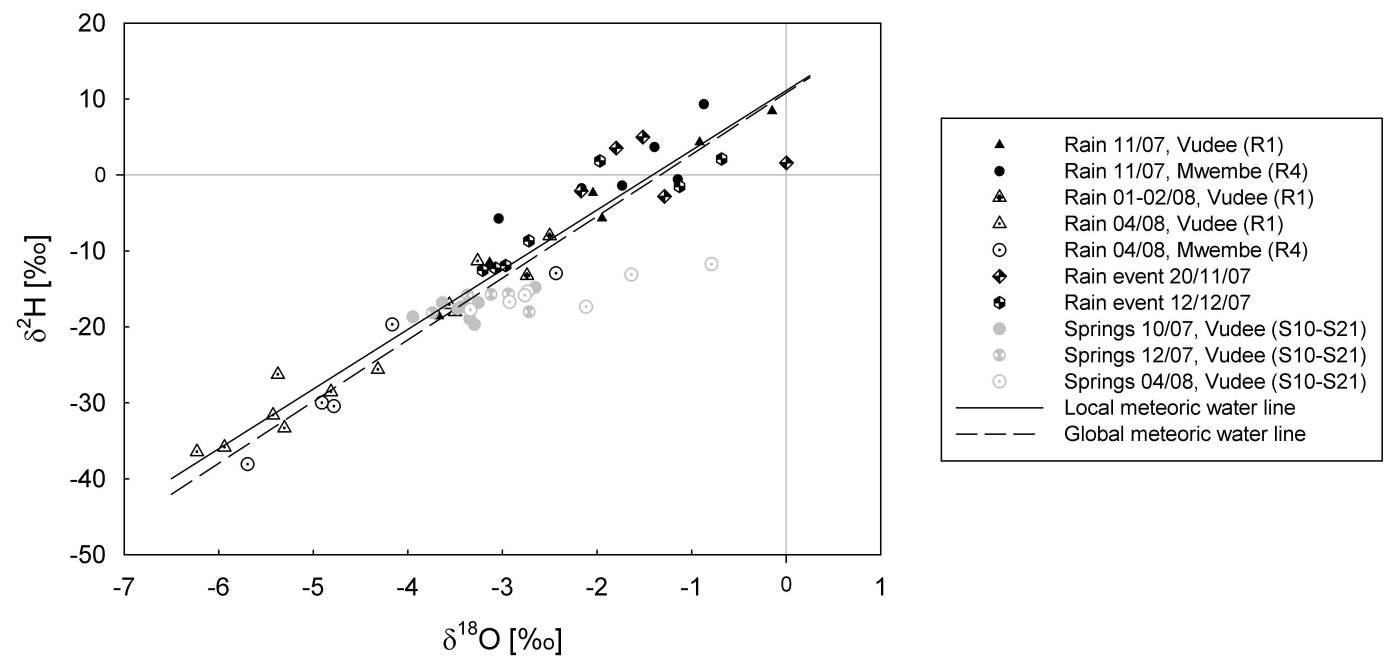

Fig. 3. Isotopic composition of rain water, sampled at Vudee (R1) and Mwembe (R4) throughout the study period as well as the composition of rain water sampled throughout the catchment during two events (20/11/2007 and 12/12/2007). Furthermore, the isotopic spring water composition of springs in Vudee (S10-S21) sampled at three occasions: at the beginning of WS1 (10/2007), the end of WS1 (12/2007) and in the middle of WS2 (04/2008).

was used, thus neglecting the influence of gradual depletion of heavy isotopes with the duration of an event (cf. Kendall and Caldwell, 1998), resulting in a potential overestimation of pre-event contributions at early stages of the events and underestimation towards the end of an event.

\subsection{Runoff analysis}

\subsubsection{Mataini catchment $\left(0.3 \mathrm{~km}^{2}\right)$}

During the observation period (13 March-30 April 2008) ten different events (M1-M10) could be distinguished in the Mataini catchment (Fig. 2a). A summary of the events can be found in Table 1. On visual inspection, the catchment exhibited a flashy event runoff response, while base flow showed a comparably slowly draining groundwater reservoir. According to the MRC analysis, the groundwater reservoir was characterized by a storage coefficient $k_{\mathrm{B}}=0.059 \mathrm{~d}^{-1}$ or timescale $t_{\mathrm{B}}=17 \mathrm{~d}$ (inset in Fig. 2a). During events M1-M4 base flow remained very low and only after a period of seven consecutive days with rain, yielding a total of $145 \mathrm{~mm}$, and a subsequent high yield but low intensity event on 27 March 2008 (M5), significant volumes of water infiltrated and recharged the groundwater. This is illustrated by sharp increases of base flow and groundwater level in the piezometer at this moment. Analysis of the event runoff coefficient $C_{\mathrm{E}}$ gave further insights into the functioning of this catchment, particularly as besides the $C_{\mathrm{E}}$ the storage coefficient $k_{\mathrm{DE}}$ of the reservoir generating direct flow had to be estimated as well (Table 1). The flashy nature of the catchment was again highlighted by the values of $k_{\mathrm{DE}}$, which were up to three orders of magnitude above the baseflow storage coefficient $k_{\mathrm{B}}$. Relating $k_{\mathrm{DE}}$ to several metrics of catchment wetness, it was found, using a best subset multiple regression approach based on weighted covariances, that it is highly significantly related to the combined influences of precipitation intensity, precipitation amount and the antecedent precipitation amount of the preceding 5 days $\left(\mathrm{AP}_{5}\right)$, with $R^{2}=0.90(p<0.001$, $n=10$ ). In other words, $k_{\mathrm{DE}}$, which per definitionem should be a quasi-static descriptor of effective hydraulic conductivity, is increasing with increasing catchment wetness, thus the wetter the conditions, the faster water is routed through the soil:

$Q_{\mathrm{E}}(t, w)=S_{\mathrm{E}}(t) k_{\mathrm{DE}}(w(t))$

where $Q_{\mathrm{E}}(t, w)$ is the event runoff, $S_{\mathrm{E}}(t)$ is the storage and $w$ is an indicator of catchment wetness. This reflects the non-linear properties of the rapid flow mechanisms in the sense of a deviation from a linear storage- discharge relationship: the more water is made available by high intensity precipitation events and the wetter the catchment, the disproportionally faster the direct flow mechanisms respond. This is illustrated in Fig. 5 with a thought experiment where the hypothetical storage - discharge relationship of a linear reservoir, i.e. $k_{\mathrm{D}}=$ const., is shown together with a synthetic storage - discharge relationship derived from a value $k_{\mathrm{D}}$ that is linearly related to a hypothetic metric of catchment wetness (Eq. 10), here the 5-day antecedent precipitation amount. The deviation from the linear response can be interpreted as a mechanism similar to transmissivity feedback (Bishop, 1991) with gradual activation of rapid flow paths, potentially including macro-pores but, for larger scale events also infiltration overland flow, supported by the presence of pronounced soil erosion features and by substantially increased $k_{\mathrm{DE}}$ values for the highest intensity events, 
a) Spring samples
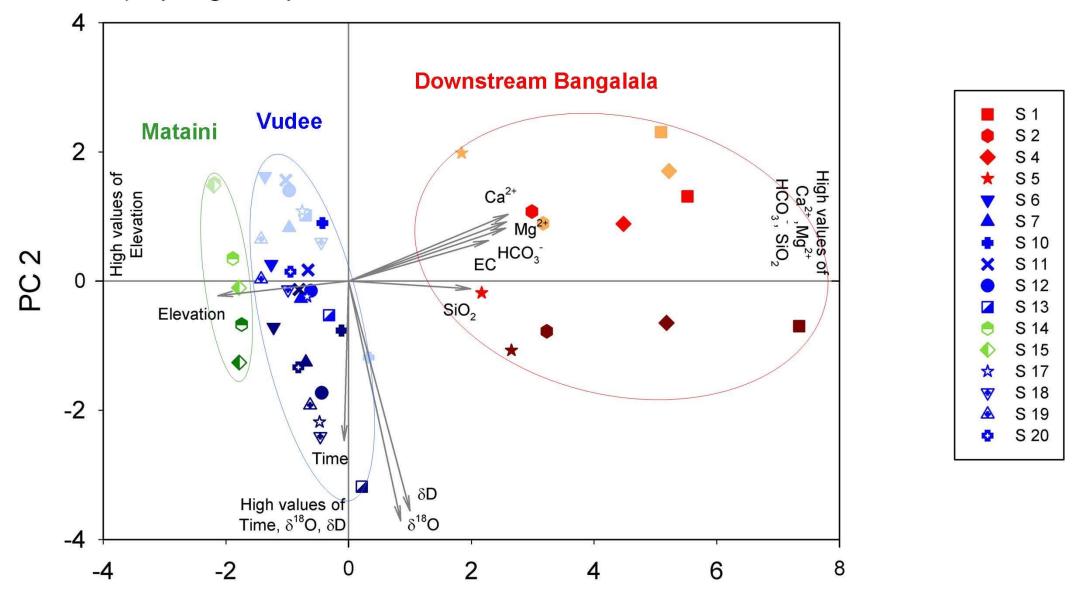

b) Groundwater, stream and rain samples

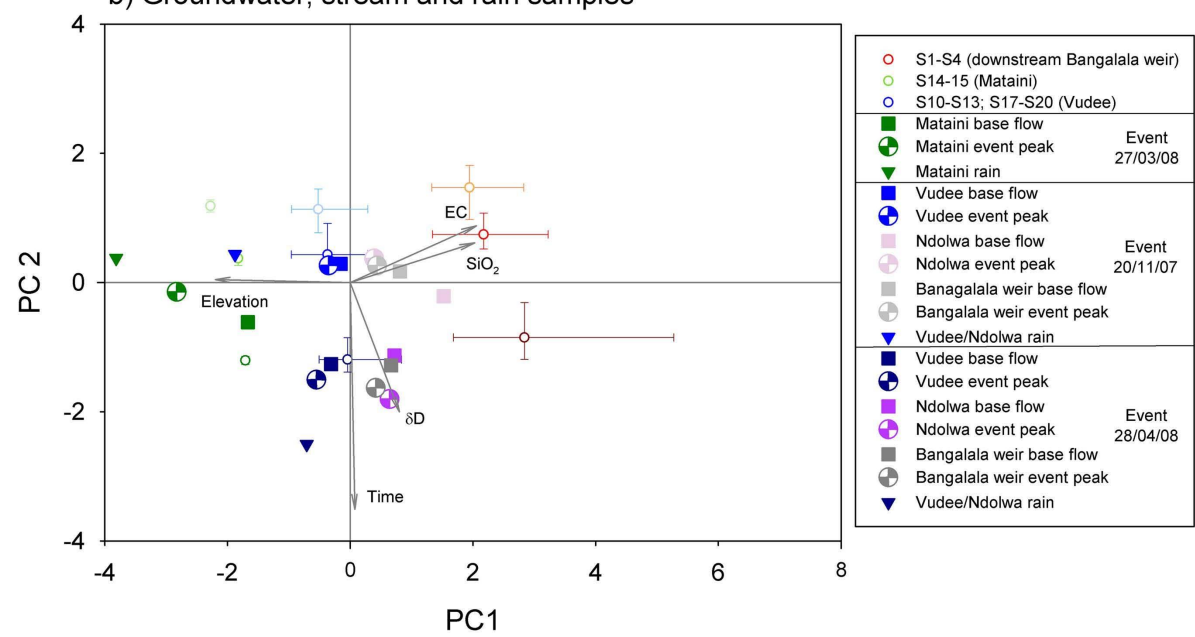

Fig. 4. (a) shows a Principle Component Analysis (PCA) based on elevation (as a proxy for location) and time elapsed since start of WS1 as well as on the geochemical $\left(\mathrm{Ca}^{2+}, \mathrm{Mg}^{2+}, \mathrm{HCO}_{3}^{-}, \mathrm{SiO}_{2}, \mathrm{EC}\right)$ and isotopic $\left(\delta D, \delta^{18} \mathrm{O}\right)$ composition of spring water samples $(\mathrm{S} 1-\mathrm{S} 20)$ at three sampling dates at the beginning of WS1 (10/2007), the end of WS1 (12/2007) and in the middle of WS2 (04/2008). The different symbols represent the different springs while the different shades represent the sampling date, i.e. points with lightest shade were sampled at the first occasion (10/2007), the points with the darkest shades were sampled at the last occasion (04/2008). (b) shows a PCA based on a reduced data set, as the complete geochemical and isotopic signature of stream water samples was not available for all samples. It is thus based on elevation (as a proxy for location) and time elapsed since start of WS1 as well as on the geochemical $\left(\mathrm{SiO}_{2}, \mathrm{EC}\right)$ and isotopic $(\delta D)$ composition of the mean and $95 \%$ inter-quantile ranges of the spring samples (S1-S20), the composition of baseflow, peak event flow and event rain samples at Mataini, Vudee, Ndolwa and Bangalala, sampled during 2 events (20/11/2007 and 28/04/2008). Lighter shades indicate earlier dates, while darker shades again indicate events later in the study period.

e.g. $k_{\mathrm{DE}}=41.5 \mathrm{~d}^{-1}\left(\mathrm{UI}_{95 L}=22.873 .1 \mathrm{~d}^{-1}\right)$ or time scale $t_{\mathrm{DE}}=0.02 \mathrm{~d}\left(\mathrm{UI}_{95 L}=0.010 .04 \mathrm{~d}\right)$ for event $\mathrm{M} 2$, as compared to $k_{\mathrm{DE}}$ and $t_{\mathrm{DE}}$ values below $10 \mathrm{~d}^{-1}$ and above $0.10 \mathrm{~d}$, respectively, for lower intensity events (Table 1).

The event runoff coefficients were generally very low with $0.9 \leq C_{\mathrm{E}} \leq 5.9 \%$. Considering the aridity index $I_{\mathrm{A}}>2.5$ of the study area, these results fall well into the range of what was reported by others for catchments with comparable, i.e. semi-arid, climate conditions (e.g. Wenninger et al., 2008). Changes in $C_{\mathrm{E}}$ were found to be linked to changes in base flow $\left(R^{2}=0.71, p=0.002, n=10\right)$ and $\mathrm{AP}_{5}\left(R^{2}=0.57\right.$, $p=0.012, n=10)$. Similar to what was reported by $\mathrm{Li}$ et al. (2011) for sub-humid catchments, this is an indicator for a relation to changes in soil moisture and thus potential switches in runoff generation processes. However, the relatively modest correlation suggests potential further influences, which could not be identified with the available data.

As illustrated for event M5 in Fig. 4b, the base flow composition of stream water largely reflects the spring water composition. In comparison with the remaining three study catchments, the Mataini catchment shows a more pronounced tracer response to events, i.e. the event stream water 


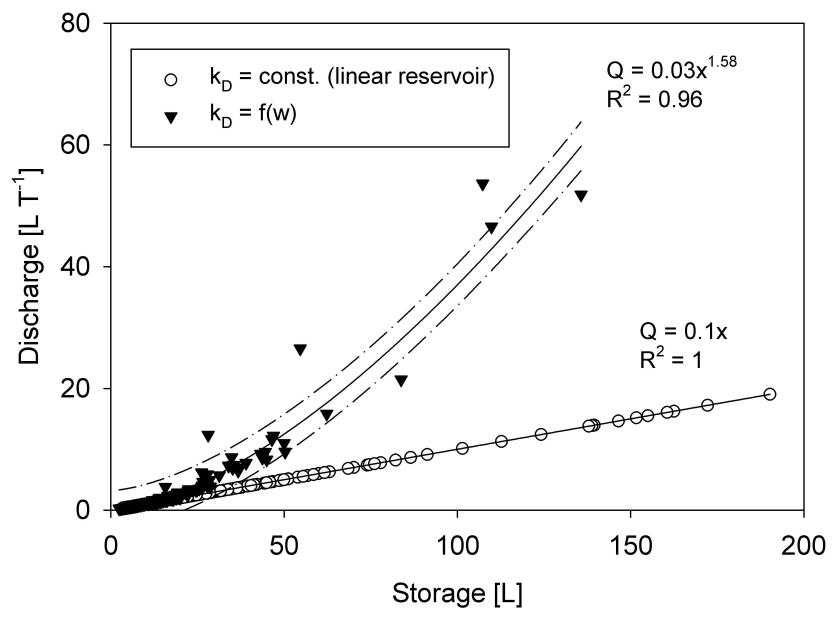

Fig. 5. Hypothetical example of storage - discharge relationships with synthetic constant $k_{\mathrm{D}}$, representing a linear reservoir and with $k_{\mathrm{D}}$ as function of catchment wetness $w$. In this example $k_{\mathrm{D}}$ was linearly related to synthetic 5-day antecedent precipitation totals.

composition changes significantly to show a signature closer to that of the event precipitation. This suggests, in particular with respect to $\delta D$, that the Mataini catchment has a lower turn-over or mean transit time than the entire Vudee catchment, which it is part of (cf. Hrachowitz et al., 2009).

Detailed event tracer data, including $\mathrm{EC}, \mathrm{SiO}_{2}$ and $\delta D$ were available for events M4 and M5 (Fig. 6). Note, that analysis using $\delta^{18} \mathrm{O}$ data was not possible due to a corrupt data file. During M4 an equivalent of $4.9 \%\left(\mathrm{UI}_{95 L}=4.2\right.$ $5.6 \%$ ) of the total event precipitation was directly discharged according to the event runoff coefficient analysis (Table 1). On average $73 \%$ (UI $95 s=63-79 \%$ ) of the total event runoff was estimated to be pre-event water, with a peak pre-event water contribution of $56 \%\left(\mathrm{UI}_{95 s}=34-58 \%\right)$. Likewise, the amount of direct runoff for M5 was found to be $5.9 \%$ (UI ${ }_{95 L}=4.3-7.4 \%$; Table 1) of the total event precipitation. The computed mean total pre-event water contribution was $63 \%$ (UI $95 s=54-75 \%$ ), with peak pre-event water contributions of $41 \%\left(\mathrm{UI}_{95 s}=39-64 \%\right)$. Approximately three hours after the peak flow the tracer concentrations returned back to pre-event levels, indicating no event water contribution during the later recession.

The multi-tracer approach, however, makes a serious limitation of the hydrograph separation method evident. Figure 6 shows the individual pre-event water contribution distributions for each tracer for a range of M5 samples. The use of three different tracers resulted in significantly different average pre-event water contribution estimates, i.e. $57 \%(\mathrm{EC})$, $65 \%\left(\mathrm{SiO}_{2}\right)$ and $74 \% \delta D$, which is also highlighted by the wide uncertainty intervals of the combined multi-tracer preevent water contribution estimate in Figs. 6 and 7. The uncertainty in the estimated combined pre-event water contributions introduced by $\delta D$ was most likely partially linked to
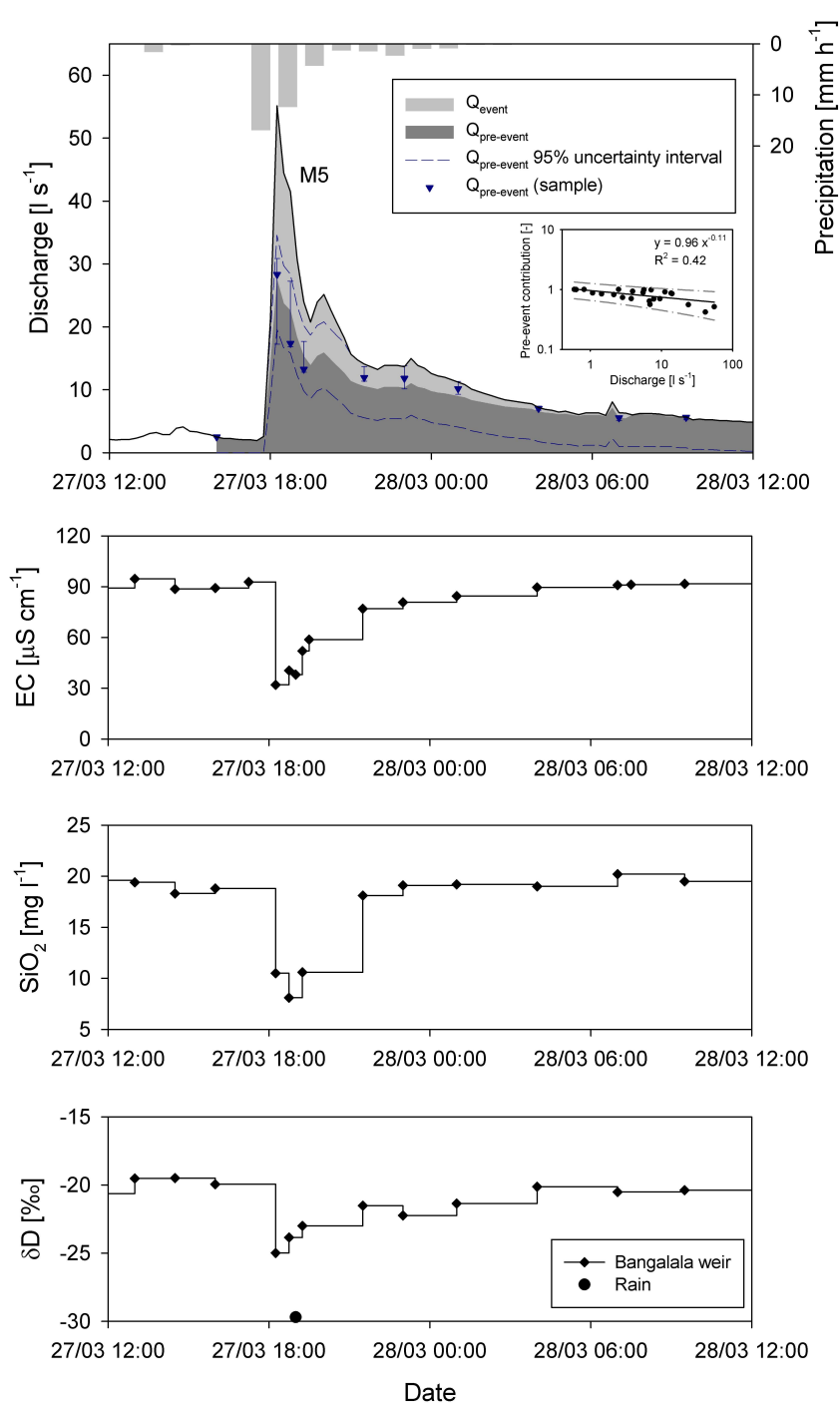

Fig. 6. The top plot shows the hydrograph separation between event $\left(Q_{\mathrm{e}}\right)$ and pre-event $\left(Q_{\mathrm{p}}\right)$ runoff for the M5 event (27/03/08, WS2) based on combined $\delta D, \mathrm{EC}$ and $\mathrm{SiO}_{2}$ measurements in the Mataini catchment. The bold black line (-) shows the total discharge $\left(Q_{\text {tot }}\right)$, the two grey shaded areas represent the central estimates for the event $(\square)$ and pre-event $(\square)$ contributions derived from a power relationship between relationship between $Q_{\text {tot }}$ and $Q_{\mathrm{p}}$, which is shown in the inset (cf. Godsey et al., 2009), and the dashed line (--) is the corresponding $95 \%$ uncertainty interval. The circle symbols $(\bullet)$ denote $\mathrm{Q}_{\mathrm{p}}$ for the individual analyzed samples, with the whiskers representing the $95 \%$ uncertainty interval. The 3 bottom plots show the available tracer data for M4 and M5.

an inadequate representation of the spatio-temporal $\delta D$ variability in the rain water end-member. In other words, more detailed event data would have allowed the incorporation of the extent of the rain out effect (Kendall and Caldwell, 1998). At early stages of the event $\delta D$ would be more enriched compared to the volume weighted, event averaged composition used in this study, resulting in lower pre-event contributions 
and more depleted, resulting in higher pre-event contribution estimates later in the event,. Thus, the resulting total uncertainty from the multi-tracer approach would be reduced as compared to the use of the event averaged value, as the $\delta D$ distribution in Fig. 7 would be shifted towards the geochemical derived distributions.

There was little evidence of non-conservative behaviour of the geochemical tracers (Uhlenbrook et al., 2002; Asano et al., 2003) in the first $\sim 5-6 \mathrm{~h}$ after the beginning of the event as the event/pre-event estimates of both $\mathrm{EC}$ and $\mathrm{SiO}_{2}$ give generally similar results, although it is frequently assumed that they have different timescales of non-conservative behaviour (e.g. Laudon and Slaymaker, 1997; Uhlenbrook et al., 2002; Asano et al., 2003; Pellerin, 2007), which would imply consistently different event/pre-event contribution estimates. Only after $>5 \mathrm{~h}$, such processes could play a significant role as the pre-event contribution estimates from the individual geochemical tracers are diverging (Fig. 7).

Note, that the considerably wider uncertainty intervals of the continuous pre-event water estimates $\left(\mathrm{UI}_{95}\right.$; dashed line in Fig. 6) compared to the uncertainty intervals of the individual samples (UI ${ }_{95 s}$; whiskers in Fig. 6) is largely owed to the uncertainty in the regression equation used to predict the preevent contributions at times where no samples were available, similar to prediction intervals in classic least-squares regression analysis (see Methods section and inset in Fig. 6).

\subsubsection{Bangalala catchment $\left(25.3 \mathrm{~km}^{2}\right)$}

A total of 18 events (B1-B18) was identified during the interrupted observation period (12 November-12 December 2007; 9 April-1 June 2008) in the Bangalala catchment (Fig. 2b). A summary of the events can be found in Table 2. Analysis of the hydrograph revealed that the Bangalala catchment showed a more subdued runoff pattern than the Mataini sub-catchment. The MRC analysis suggested a groundwater reservoir storage coefficient of $k_{\mathrm{B}}=0.034 \mathrm{~d}^{-1}$ equivalent to a timescale $t_{\mathrm{B}}=29 \mathrm{~d}$ (inset in Fig. 2b). Base flow remained essentially constantly low for the first precipitation events of WS1. It gradually started to increase with runoff event B1 (19 November 2007) to reach an observed maximum by mid-December (B14), gradually decreasing and thus draining the groundwater reservoir starting from the mid of WS2 at the latest.

The comparably attenuated stream flow pattern of the Bangalala catchment is also clearly reflected by the results of the event runoff coefficient analysis (Table 2). Although the extreme event storage coefficients $k_{\mathrm{DE}}$ were, as in the Mataini catchment, up to almost 3 orders of magnitude above the baseflow storage coefficient $k_{\mathrm{B}}$, their mean values were significantly lower than in the Mataini catchment. Best subset multiple regression analysis with weighted covariances showed that $k_{\mathrm{DE}}$ was significantly related to the same combined influences as in the Mataini catchment: precipitation intensity, precipitation amount and the antecedent precipitation amount of the preceding 5 days $\left(\mathrm{AP}_{5}\right)$, with $R^{2}=0.96(p<0.001, n=18)$. As the $k_{\mathrm{DE}}$ values remained relatively stable at values below $\sim 4 \mathrm{~d}^{-1}\left(t_{\mathrm{DE}} \sim 0.25 \mathrm{~d}\right)$ and switched rather quickly to much higher rates, $k_{\mathrm{DE}}>9 \mathrm{~d}^{-1}$ $\left(t_{\mathrm{DE}}<0.11 \mathrm{~d}\right)$ for the most intensive precipitation events only (B11 and B14), this suggests that the direct runoff component has quite a homogenous structure, i.e. almost the same flow pathways are always contributing once the component is activated independent from soil moisture. The only exception is the apparent triggering of a second rapid runoff component, most likely infiltration excess overland flow, at very high intensity events (B11 and B14; Table 2).

The event runoff coefficients were generally low with $0.8 \leq C_{\mathrm{E}} \leq 8.8 \%$, but, according to a $t$-test, significantly higher $(p=0.03)$ than the $C_{\mathrm{E}}$ in the Mataini catchment. Although less evident than for the observation period in the Mataini catchment, $C_{\mathrm{E}}$ was significantly correlated with base flow $\left(R^{2}=0.33, p=0.012, n=18\right)$ and $\mathrm{AP}_{5}\left(R^{2}=0.33\right.$, $p=0.012, n=18$ ) in the Bangalala catchment as well. This again hints towards significant, but limited influences of soil moisture and runoff generation process thresholds on $C_{\mathrm{E}}(\mathrm{Li}$ et al., 2011).

The spring water, base flow, event flow and precipitation composition of water for two events (B2 and B17) for which the complete tracer set was available $\left(\delta D, \mathrm{EC}, \mathrm{SiO}_{2}\right)$ are shown in the PCA in Fig. 4b. The base flow samples of the Vudee sub-catchment plotted very close to the spring water samples from springs in the same catchment. Base flow samples from the Ndolwa sub-catchment showed a clearly different signature for both events. Although similar in isotopic composition, base flow water from Ndolwa was significantly richer in ionic content, compared with Vudee. Base flow at Bangalala, downstream of the Vudee - Ndolwa confluence displayed an intermediate signature. The event samples for Vudee, in spite of the rather distinct rain water signatures, showed a composition very similar to the base flow samples. This damped response suggests that the Vudee catchment is characterized by a relatively high turn-over or mean transit time (cf. Hrachowitz et al., 2010b), in particular compared to the Mataini sub-catchment. The event water signature at Ndolwa, on the other hand, reveals a much stronger influence of precipitation, implying that the catchment responds more rapidly to precipitation and potentially resulting in lower catchment mean transit times.

Detailed event tracer data, were available for events B1$\mathrm{B} 4, \mathrm{~B} 8\left(\mathrm{EC}, \mathrm{SiO}_{2}\right.$, while $\delta D$ was only available for B1-B2 and thus omitted in the analysis; Fig. 8) and B17 (EC, $\mathrm{SiO}_{2}$, $\delta D$ and $\delta^{18} \mathrm{O}$; Fig. 9). For events B1-B4 and B8 the tracers where used to estimate the runoff contributions of the two sub-catchments, i.e. Vudee and Ndolwa, to flow at Bangalala. Likewise, for event B17 the geochemical tracers were used to estimate the sub-catchment contributions while additionally the isotopic tracers facilitated a hydrograph separation into event and pre-event contributions. At the beginning of WS1 before significant wet-up has taken place, i.e. B1 and B2, the 

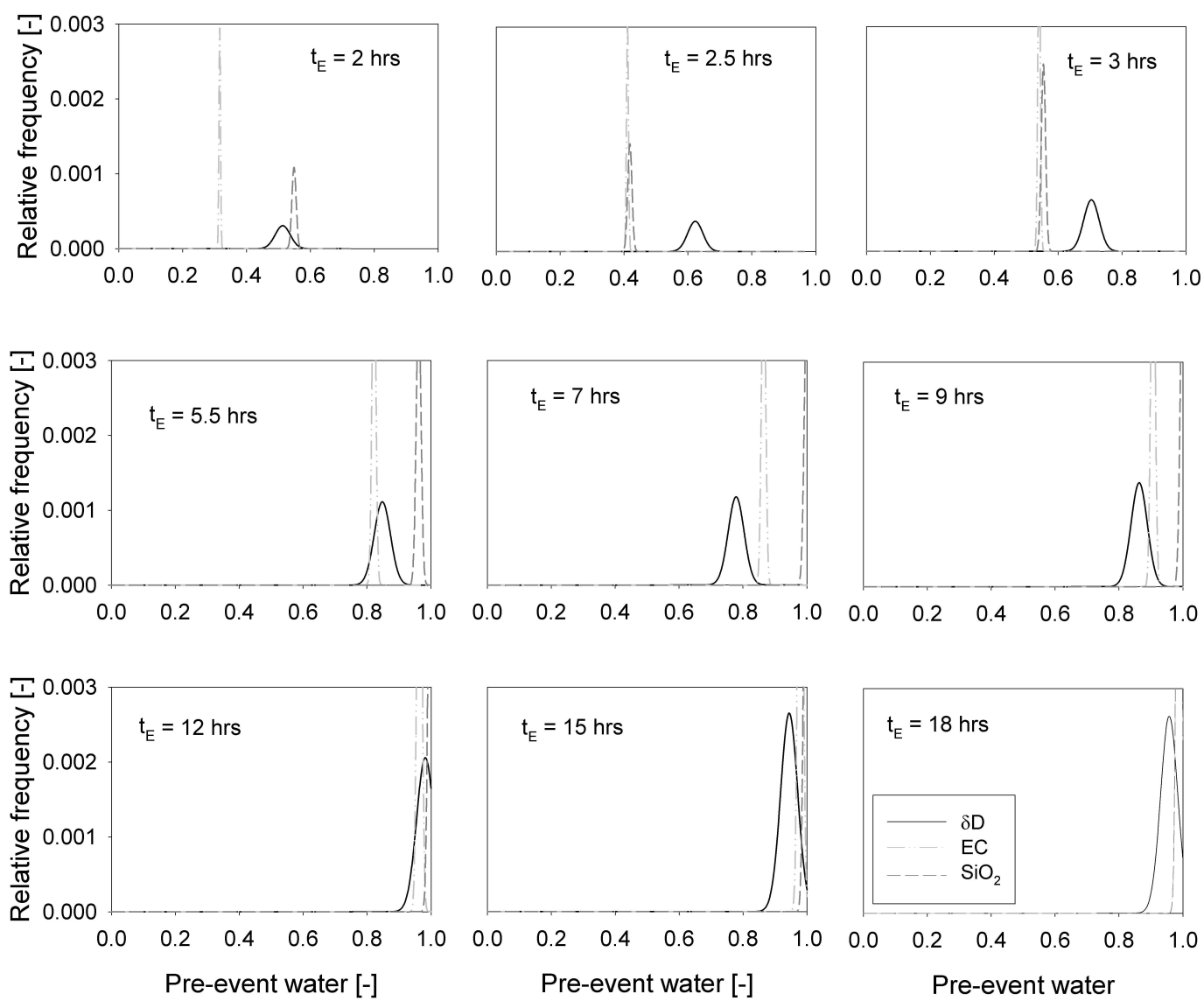

Fig. 7. Probability distributions of pre-event contributions computed with 3 different tracers $\left(\delta D, \mathrm{EC}\right.$ and $\left.\mathrm{SiO}_{2}\right)$ for the available samples of the $\mathrm{M} 5$ event. $t_{\mathrm{E}}$ denotes the time elapsed since the beginning of the event rainfall.

relative contributions of Vudee and Ndolwa roughly correspond with their respective catchment areas and precipitation amounts. Hence, for similar rain amounts, Vudee $\left(14.6 \mathrm{~km}^{2}\right)$ and Ndolwa $\left(8.8 \mathrm{~km}^{2}\right)$ contributed $\sim 66 \%\left(\mathrm{UI}_{95 s}=47-71 \%\right)$ and $\sim 34 \%$ (UI ${ }_{95 s}=29-53 \%$ ), respectively (Table 2, Fig. 8). This suggests, together with the low $C_{\mathrm{E}}$, that at this moment the groundwater reservoirs with their potentially similar storage coefficients dominated the runoff. As the catchments gradually become wetter in WS1 the situation changes and Ndolwa, in spite of the smaller catchment size and nearly equal or less precipitation contributes more to the total runoff at Bangalala than Vudee (B3, B4 and B7), with a maximum contribution from Ndolwa of $63 \%\left(\mathrm{UI}_{95 s}=52-73 \%\right)$ during B17, when also the base flow is highest (Fig. 2b). The pre-event water contribution is high during B17, with $71 \%\left(\mathrm{UI}_{95 s}=41-98 \%\right)$ and $95 \%\left(\mathrm{UI}_{95 s}=71-100 \%\right)$, respectively, for Ndolwa and Vudee (Fig. 9). In other words, the $17 \%$ (UI $\mathrm{U}_{95}=3-32 \%$ ) of the total runoff at Bangalala is event water originating from Ndolwa and merely $2 \%$ $\left(\mathrm{UI}_{95 s}=0-7 \%\right)$ of the total runoff is event water from originating from Vudee. Together with the findings from Fig. 4b, that the event stream water composition at Ndolwa is less attenuated than at Vudee, this supports the theory that once a certain level of catchment wetness is reached, event water is drained from the Ndolwa catchment more efficiently and rapidly, most likely caused by the presence of a denser preferential flow path network and/or less storage availability. As was the case for the Mataini catchment, the results for both, the event/pre-event as well as the geographical hydrograph separation, are subject to high uncertainties when applying multiple tracers $\left(\mathrm{UI}_{95 s}\right.$ and $\mathrm{UI}_{95 c}$ in Figs. 8 and 9). For example, the relative contribution from Ndolwa during B8 was $58 \%\left(\mathrm{UI}_{95 s}=41-71 \%\right)$ as computed with the multi-tracer approach, while it was $67 \%$ and $46 \%$ using $\mathrm{EC}$ and $\mathrm{SiO}_{2}$ only. While some of the uncertainty here can be attributed to the fact that Bangalala is $1 \mathrm{~km}$ downstream of the Vudee/Ndolwa confluence, this additional, geochemically uncharacterized part of the catchment cannot explain the entire uncertainty as it accounts only for $8 \%$ of the total catchment area. Although no conclusive answer can be given at this point, these uncertainties, also evident in the Mataini catchment, are assumed to result from incomplete mixing and temporal lags between runoff originating from different, geochemically distinct parts of the catchment. 

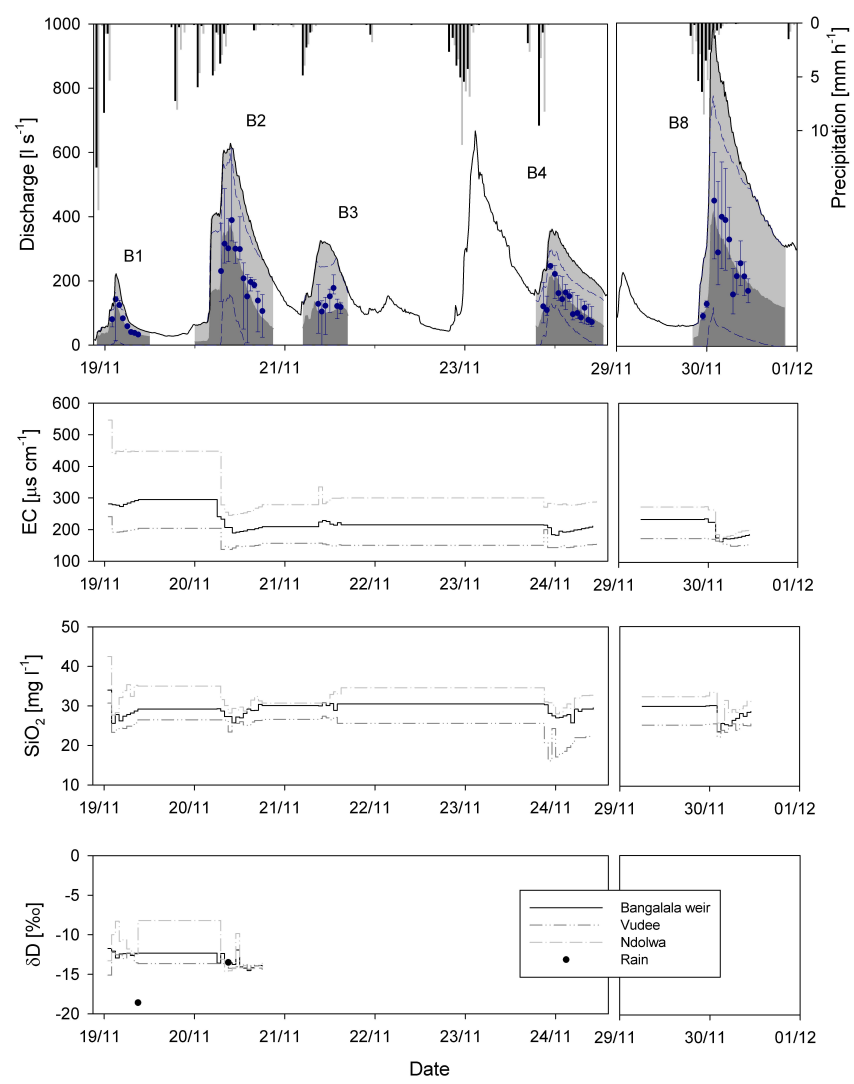

Fig. 8. Top shows the runoff contributions from Vudee $\left(Q_{\text {vud }}\right)$ and Ndolwa $\left(Q_{\mathrm{Ndol}}\right)$ catchments to the runoff recorded at Bangalala for the period of 18-30/11/2007 (B1-B4, B8) in which detailed tracer data were available. Analysis is based on combined $\mathrm{EC}$ and $\mathrm{SiO}_{2}$ measurements. The bold black line (-) shows the total discharge $\left(\mathrm{Q}_{\text {tot }}\right)$ observed at the Bangalala weir, the two grey shaded areas represent the central estimates for the contributions from the Vudee $(\square)$ and Ndolwa $(\square)$ catchments derived from a power relationship between relationship between $Q_{\text {tot }}$ and $Q_{\text {vud }}$ and the dashed line (--) is the corresponding $95 \%$ uncertainty interval. The circle symbols $(\bullet)$ denote $Q_{\text {vud }}$ for the individual analyzed samples, with the whiskers representing the $95 \%$ uncertainty interval. Bottom three figures show observed $\mathrm{EC}$ and $\mathrm{SiO}_{2}$ concentrations at the Bangalala weir, as well as in the Vudee and Ndolwa catchments.

\section{Wider implications and conclusions}

The results illustrate that for catchments with medium to flashy stream flow responses in a semi-arid environment event runoff coefficients tend to be very low $\left(0.8 \leq C_{\mathrm{E}} \leq 8.8 \%\right)$. Changes in $C_{\mathrm{E}}$ were shown to be linked to changes in baseflow and antecedent precipitation. While, little surprisingly, groundwater sustained the flow in dry periods, rapid flow generation processes were activated once the catchment was wet-up. For high intensity high yield events an additional fast flow component, potentially infiltration overland flow, was triggered. This is concluded from the by factor $\sim 2$ increased rate of change of the storage

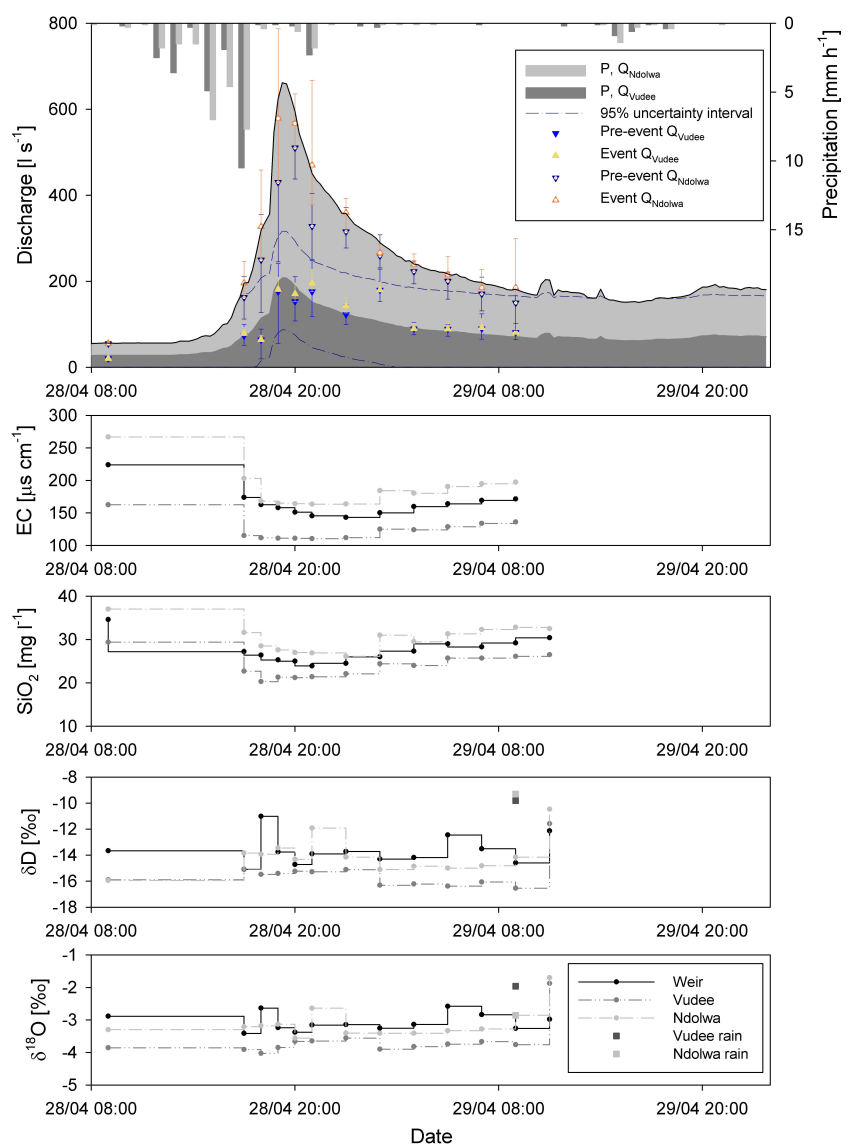

Fig. 9. Top figure shows hydrograph separation between event $\left(Q_{\mathrm{e}}\right)$ and pre-event $\left(Q_{\mathrm{p}}\right)$ discharge from the Vudee $\left(Q_{\mathrm{vud}}\right)$ and Ndolwa $\left(Q_{\mathrm{Ndol}}\right)$ catchments for the B17 event (28/04/2008) of the Masika'08 season. Contributions from $Q_{\text {vud }}$ and $Q_{\text {Ndol }}$ estimated using combined EC and $\mathrm{SiO}_{2}$ measurements. Separation into $Q_{\mathrm{e}}$ and $Q_{\mathrm{p}}$ based on combined $\delta D$ and $\delta^{18} \mathrm{O}$ measurements. The bold black line (-) shows the total discharge ( $\left.Q_{\text {tot }}\right)$ observed at the Bangalala weir, the two grey shaded areas represent the central estimates for the contributions from the Vudee $(\square)$ and Ndolwa ( $\square$ ) catchments derived from a power relationship between relationship between $Q_{\text {tot }}$ and $Q_{\text {vud }}$ and the dashed line (--) is the corresponding $95 \%$ uncertainty interval. The yellow $(\Delta)$ and light blue triangles ( $\nabla$ ) denote $Q_{\mathrm{e}}$ and $Q_{\mathrm{p}}$ contributions from $Q_{\mathrm{vud}}$, while the orange $(\Delta)$ and dark blue triangles $(\nabla)$ represent the $Q_{\mathrm{e}}$ and $Q_{\mathrm{p}}$ contributions from $Q_{\mathrm{Ndol}}$ for the individual analyzed samples, with the whiskers representing the $95 \%$ uncertainty interval.

coefficient $k_{\mathrm{DE}}$ and supported by the abundance of rill and gully erosion features in the agricultural fields in the upper catchment. However, these results should be interpreted in the context of the relatively wet conditions during the study period, as compared to long-term averages. The strong relationship between metrics of precipitation with $k_{\mathrm{DE}}$, can be interpreted as a proxy of the degree of activation of rapid flow pathways. It is thus implicit that during drier years rapid flow pathways are triggered to a lesser degree, highlighting 
the increased dominance of groundwater-sustained flow during these periods. Likewise, the event runoff coefficients $C_{\mathrm{E}}$ can be expected to show a trend towards even lower maximum annual values as a result of reduced catchment wet-up in drier years.

Furthermore, pre-event water was shown to be the dominant source of runoff during events in this study. Earlier studies in semi-arid areas showed varying results with preevent water contributions between 30 and $90 \%$, mostly dependent on the rainfall intensities (e.g. McCartney et al., 1998; Sandström, 1996; Wenninger et al., 2008; Mul et al., 2008, 2009). High pre-event water contributions were previously shown to be a common feature for a wide range of catchments in humid settings, i.e. the "old water paradox" (e.g. Kirchner, 2003). The driving process behind the rapid mobilization of subsurface flow is still discussed in hydrology and many processes were suggested, e.g. groundwater ridging (e.g. Gilham, 1984), transmissivity feedback (e.g. Bishop, 1991), macropore flow (e.g. McDonnell, 1990), kinematic waves (e.g. Nolan and Hill, 1990), as well as the fill and spill hypothesis (Tromp-van Meerveld and McDonnell, 2006). Recently, Jones et al. (2006) and Renaud et al. (2007) discussed the influence diffusive processes have on tracer exchange between runoff components disguising discharge generating processes, causing the interpretation of tracer information and therefore water movement being potentially more complex than it was perceived until now. The combined tracer and event runoff analysis helped to gain a better understanding of the spatio-temporal differences in the functioning of different parts of the Bangalala catchment, where very fast responding headwaters are in contrast with a comparably subdued flow regime further downstream.

In this study, multiple tracers, i.e. $>n-1$, were used to estimate and compare the respective $n$ component contributions to runoff in a small catchment, which was previously only attempted by a handful of publications (e.g. Laudon and Slaymaker, 1997), focussing on humid climates, rather than semi-arid, data-scarce areas. Even less published work aimed at actually quantifying and interpreting different sources of uncertainty (Uhlenbrook and Hoeg, 2003), particularly resulting from such multiple tracer applications (e.g. Rice and Hornberger, 1998). Independently using multiple tracers, they reported widely varying estimates of "groundwater" contribution, i.e. with ranges of up to $21-79 \%$, for single events, depending on the tracers used, while Pellerin et al. (2007) only reported small differences between event/pre-event contribution estimates using different tracers. Here, we found that for the event with the highest associated uncertainty (B17) the estimated pre-event contributions using different tracers varied between 51 and $92 \%$ (Ndolwa, $\mathrm{UI}_{95 s}=41-98 \% ; \delta D$ and $\delta^{18} \mathrm{O}$ ), while the highest uncertainty in contribution estimates from different geographical sources was found for $\mathrm{B} 2$ with a range of 41 to $65 \%\left(\mathrm{UI}_{95 s}=36-70 \%\right.$; $\mathrm{EC}$ and $\left.\mathrm{SiO}_{2}\right)$. These uncertainties were partly attributed to an imperfect sampling protocol with insufficient representation of spatio-temporal variability in rain water composition as well as the fact that a small part of the catchment, between the Vudee/Ndolwa confluence and Bangala, was not considered at all. However, these sources of uncertainty are not exhaustive and the results of this study highlight the need for caution when interpreting results from hydrograph separation and mixing studies (cf. Godsey et al., 2009). In the absence of any further detailed knowledge about tracer dynamics in individual catchments results from studies based on single tracers can potentially be very misleading. Although not advocated as the perfect solution of the problem, multi-tracer approaches at least allow for more robust estimates and help to avoid the most extreme misrepresentations.

This study shows the value of hydrological data collection over one whole wet season using multiple tracers and hydrometric data to infer dominant hydrological processes. The analysis revealed considerable spatio-temporal heterogeneity in catchment function between the four nested subcatchments. The small Mataini headwater sub-catchment showed a comparably flashy response with short turnover times and pronounced switches between dominant runoff processes, indicating a potential abundance of rapid flow pathways. In contrast, the response at the outlet of the largest catchment, Bangalala showed a much more subdued response with more subtle activation of rapid flow pathways, indicating an event response that is controlled by fewer individual processes. Combined tracer and runoff analysis also showed that the Vudee and Ndolwa sub-catchments themselves have distinct hydrological properties. The Ndolwa is subject to more pronounced threshold processes and faster storm response and the Vudee catchment response closer to linear. This study can be seen as example how short and intense field-based hydrological data collection can help to extract considerable information on catchment function, which in turn is crucial for enhanced sustainability in water resources management in data scarce, semi-arid environments.

Acknowledgements. The work reported here was undertaken as part of the Smallholder System Innovations in Integrated Watershed Management (SSI) Programme funded by the Netherlands Foundation for the Advancement of Tropical Research (WOTRO), the Swedish International Development Cooperation Agency (Sida), the Netherlands Directorate-General of Development Cooperation (DGIS), the International Water Management Institute (IWMI) and UNESCO-IHE, Institute for Water Education. Implementation on site was assisted by the Soil-Water Management Research Group (SWMRG) of Sokoine University of Agriculture, Tanzania. The authors would like to thank those who helped with instrumentation, sampling and lab analyses, both in the Netherlands and Tanzania. Special thanks go to the Lamminga fund, the fund International Internships and Delft University of Technology for covering travel expenses to Tanzania. The authors would like to thank the thorough and constructive comments of the two anonymous reviewers which improved the paper greatly.

Edited by: E. Zehe 


\section{References}

Anderson, A. E., Weiler, M., Alila, Y., and Hudson, R. O.: Dye staining and excavation of a lateral preferential flow network, Hydrol. Earth Syst. Sci., 13, 935-944, doi:10.5194/hess-13-9352009, 2009.

Asano, Y., Uchida, T., and Ohte, N.: Residence times and flow paths of water in steep unchanneled catchments, Tanakami, Japan, J. Hydrol., 261, 173-192, 2002.

Asano, Y., Uchida, T., and Ohte, N.: Hydrologic and geochemical influences on the dissolved silica concentration in natural water in a steep headwater catchment, Geochim. Cosmochim. Ac., 67(11), 1973-1989, 2003.

Bagnall, P. S.: The geology of the North Pare Mountains, Bulletin of the Geological Survey of Tangayika, 10, 7-16, 1963.

Beven, K. J. and Binley, A. M.: The future of distributed models: Model calibration and uncertainty prediction, Hydrol. Process., 6, 279-298, 1992.

Birkel, C., Dunn, S. M., Tetzlaff, D., and Soulsby, C.: Assessing the value of high-resolution isotope tracer data in the stepwise development of a lumped conceptual rainfall-runoff model, Hydrol. Process., 24, 2335-2348, 2010.

Birkel, C., Tetzlaff, D., Dunn, S. M. and Soulsby, C.: Using lumped conceptual rainfall-runoff models to simulate daily isotope variability with fractionation in a nested mesoscale catchment, Adv. Water Res. 34, 383-394, doi:10.1016/j.advwatres.2010.12.006, 2011.

Bishop, K. H.: Episodic increases in stream acidity, catchment flow pathways and hydrograph separation, $\mathrm{PhD}$ thesis, Cambridge Univ., Cambridge, UK, 241 pp., 1991.

Blume, T., Zehe, E., Reusser, D. E., Iroume, A., and Bronstert, A.: Investigation of runoff generation in a pristine, poorly gauged catchment in the Chilean Andes I: A multimethod experimental study, Hydrol. Process., 22(18), 36613675, doi:10.1002/hyp.6971, 2008.

Brooks, J. R., Barnard, H. R., Coulombe, R., and McDonnell, J. J.: Ecohydrologic separation of water between trees and streams in a Mediterranean climate, Nat. Geosci., 3, 100-104, 2009.

Budyko, M. I.: Climate and Life, Academic Press, Orlando, USA, 508 pp., 1974.

Buttle, J. M.: Isotope hydrograph separations and rapid delivery of pre-event water from drainage basins, Prog. Phys. Geog., 18(1), 16-41, 1994.

Buttle, J. M. and Peters, D. L.: Inferring hydrological processes in a temperate basin using isotopic and geochemical hydrograph separation: a re-evaluation, Hydrol. Process., 11, 557-573, 1997.

Capell, R., Tetzlaff, D., Hartley, A. J., and Soulsby, C.: Linking metrics of hydrological function and transit times to landscape controls in a heterogeneous mesoscale catchment, Hydrol. Process., in press, doi:10.1002/hyp.8139, 2011.

Chapman, T. G. and Maxwell, A. I.: Baseflow separation - comparison of numerical methods with tracer experiments, I.E. Aust. Natl. Conf. Publ. 96/05, 5390-545, 1996.

Christophersen, N., Neal, C., Hooper, R. P., Vogt, R. D., and Anderson, S.: Modeling streamwater chemistry as a mixture of soilwater endmembers - a step towards second generation acidifcation models, J. Hydrol., 116, 307-320, 1990.

Clark, I. and Fritz, P.: Environmental Isotopes in Hydrogeology, CRC Press, 1997.

Dunn, S. M., Vinogradoff, S. I., Thornton, G. J. P., Bacon, J. R.,
Graham, M. C., and Farmer, J. G.: Quantifying hydrological budgets and pathways in a small upland catchment using a combined modeling and tracer approach, Hydrol. Process., 20(14), 30493068, 2006.

Durand, P. and Torres, J. J. L.: Solute transfer in agricultural catchments: the interest and limits of mixing models, J. Hydrol., 181(1-4), 1-22, 1996.

Fenicia, F., Savenije, H. H. G., Matgen, P., and Pfister, L.: Is the groundwater reservoir linear? Learning from data in hydrological modelling, Hydrol. Earth Syst. Sci., 10, 139-150, doi:10.5194/hess-10-139-2006, 2006.

Freer, J., Ambroise, B., and Beven, K. J.: Bayesian estimation of uncertainty in runoff prediction and the value of data: An application of the GLUE approach, Water Resour. Res., 32, 21612173, 1996.

Genereux, D.: Quantifying uncertainty in tracer-based hydrograph separations, Water Resour. Res., 34, 915-919, 1998.

Gilham, R. W.: The capillary fringe and its effect on watertable response, J. Hydrol., 67, 307-324, 1984.

Godsey, S. E., Kirchner, J. W., and Clow, D. W.: Concentrationdischarge relationships reflect chemostatic characteristics in US catchments, Hydrol. Process., 23, 1844-1864, 2009.

Hoeg, S., Uhlenbrook, S., and Leibundgut, C.: Hydrograph separation in a mountainous catchment - combining hydrochemical and isotopic tracers, Hydrol. Process., 14(7), 1199-1216, 2000.

Hrachowitz, M., Soulsby, C., Tetzlaff, D., Dawson, J. J. C., Dunn, S. M., and Malcolm, I. A.: Using long-term data sets to understand transit times in contrasting headwater catchments, J. Hydrol., 367, 237-248, doi:10.1016/j.jhydrol.2009.01.001, 2009.

Hrachowitz, M., Soulsby, C., Tetzlaff, D., and Speed, M.: Catchment transit times and landscape controls - does scale matter?, Hydrol. Process., 24, 117-125, doi:10.1002/hyp.7510, 2010a.

Hrachowitz, M., Soulsby, C., Tetzlaff, D., and Malcolm, I. A.: Gamma distribution models for transit time estimation in catchments: Physical interpretation of parameters and implications for time-variant transit time assessment, Water Resour. Res. 46, W10536, doi:10.1029/2010WR009148, 2010b.

Hrachowitz, M., Soulsby, C., Imholt, C., Malcolm, I. A., and Tetzlaff, D.: Thermal regimes in a large upland salmon river: a simple model to identify the influence of landscape controls and climate change on maximum temperatures, Hydrol. Process., 24, 3374-3391, 2010c.

Jones, J., Sudicky, E., Brookfield, A., and Park, Y.: An assessment of the tracer based approach to quantifying groundwater contributions to streamflow, Water Resour. Res., 42(2), W02407, doi:10.1029/2005WR004130, 2006.

Kendall, C. and Caldwell, E.A.: Fundamentals of isotope geochemistry, in: Isotope Tracers in Catchment Hydrology, edited by: Kendall, C. and McDonnell, J.J., Elsevier Science, Amsterdam, 51-86, 1998.

Kessler, T. A.: Investigation of runoff generation responses in steep, semi-arid headwater catchments, South Pare Mountains, Diploma thesis Universität Stuttgart, 102 pp., 2008.

Kirchner, J. W.: A double paradox in catchment hydrology and geochemistry, Hydrol. Process., 17, 871-874, 2003.

Kongo, V. M., Kosgei, J. R., Jewitt, G. P. W., and Lorentz, S. A.: Establishment of a catchment monitoring network through a participatory approach in a rural community in South Africa, Hydrol. Earth Syst. Sci., 14, 2507-2525, doi:10.5194/hess-14-2507- 
2010, 2010.

Lamb, R. and Beven, K.: Using interactive recession curve analysis to specify a general catchment storage model, Hydrol. Earth Syst. Sci., 1, 101-113, doi:10.5194/hess-1-101-1997, 1997.

Laudon, H., Sjöblom, V., Buffam, I., Seibert, J., and Mörth, M.: The role of catchment scale and landscape characteristics for runoff generation of boreal streams, J. Hydrol., 344, 198-209, 2007.

Li, H., Sivapalan, M., and Tian, F.: Comparative diagnostic analysis of runoff generation processes in Oklahoma DMIP2 basins: The Blue River and the Illinois River, J. Hydrol., in press, doi:10.1016/j.jhydrol.2010.08.005, 2011.

Lis, G., Wassenaar, L., and Hendry, M.: High-Precision Laser Spectroscopy D/H and 18O/16O Measurements of Microliter Natural Water Samples, Anal. Chem., 80(1), 287-293, 2008.

Love, D., Uhlenbrook, S., Corzo-Perez, G., Twomlow, S., and Van der Zaag, P.: Rainfall-interception-evaporation-runoff relationships in a semi-arid catchment, northern Limpopo basin, Zimbabwe, Hydrol. Sci. J., 55(5), 687-703, 2010.

Lyon, S. W., Laudon, H., Seibert, S., Mörth, M., Tetzlaff, D., and Bishop, K. H.: Controls on snowmelt water mean transit times in northern boreal catchments, Hydrol. Process., 24, 1672-1684, 2010.

Makurira, H., Savenije, H. H. G., and Uhlenbrook, S.: Modelling field scale water partitioning using on-site observations in subSaharan rainfed agriculture, Hydrol. Earth Syst. Sci., 14, 627638, doi:10.5194/hess-14-627-2010, 2010.

McCartney, M. P., Neal, C., and Neal, M.: Use of deuterium to understand runoff generation in a headwater catchment containing a dambo, Hydrol. Earth Syst. Sci., 2, 65-76, doi:10.5194/hess-265-1998, 1998.

McDonnell, J. J.: A Rationale for Old Water Discharge Through Macropores in a Steep, Humid Catchment, Water Resour. Res., 26, 2821-2832, 1990.

McGuire, K. J., McDonnell, J. J., Weiler, M., Kendall, C., McGlynn, B. L., Welker, J. M., and Seibert, J.:, The role of topography on catchment-scale water residence time, Water Resour Res., 41, W05002, doi:10.1029/2004WR003657, 2005.

Merz, R., Blöschl, G., and Parajka, J.: Spatio-temporal variability of event runoff coefficients, J. Hydrol., 331, 591-604, 2006.

Mul, M. L.: Understanding hydrological processes in an ungauged catchment in sub-Saharan Africa, PhD thesis, 130 pp., UNESCO-IHE Delft, The Netherlands, 2009.

Mul, M. L., Savenije, H. H. G., Uhlenbrook, S., and Voogt, M.: Hydrological assessment of Makanya catchment in South Pare Mountains, semiarid northern Tanzania, IAHS Publication, 308, 31-37, 2006.

Mul, M. L., Mutiibwa, R. K., Foppen, J. W. A., Uhlenbrook, S., and Savenije, H. H. G.: Identification of groundwater flow systems using geological mapping and chemical spring analysis in South Pare Mountains, Tanzania, Phys. Chem. Earth, 32(15-18), 10151022, 2007.

Mul, M. L., Mutiibwa, R. K., Uhlenbrook, S., and Savenije, H. H. G.: Hydrograph separation using hydrochemical tracers in the Makanya catchment, Tanzania, Phys. Chem. Earth, 33(1-2), 151-156, 2008

Mul, M. L., Savenije, H. H. G., and Uhlenbrook, S.: Spatial rainfall variability and runoff response during an extreme event in a semi-arid catchment in the South Pare Mountains, Tanzania, Hydrol. Earth Syst. Sci., 13, 1659-1670, doi:10.5194/hess-13-
1659-2009, 2009.

Nash, J. E. and Sutcliffe, J. V.: River flow forecasting through conceptual models, 1, A discussion of principles, J. Hydrol., 10, 282-290, 1970.

Newman, B., Tanweer, A., and Kurttas, T.: IAEA Standard Operating Procedure for the Liquid-Water Stable Isotope Analyser Rev 11, IAEA Water Resources Programme, available at: http://www-naweb.iaea.org/napc/ih/document/Laser, $\% 20$ Spectroscopy/laserprocedurerev11.pdf (last access: 8 January 2010), 2009.

Nieuwolt, S.: Breezes along the Tanzanian east coast, Theor. Appl. Climatol., 21(2), 189-206, 1973.

Nolan, K. M. and Hill, B. R.: Storm-runoff generation in the Permanente Creek drainage catchment, west central California - an example of flood-wave effects on runoff composition, J. Hydrol., 113, 343-367, 1990.

Pellerin, B. A., Wollheim, W. M., Feng, X., and Vörösmarty, C. J.: The application of electrical conductivity as a tracer for hydrograph separation in urban catchments, Hydrol. Process., 22, 1810-1818, 2007.

Ponce, V. M., Pandey, R. P., and Ercan, S.: Characterization of drought across climatic spectrum, J. Hydrol. Eng. ASCE, 5(2), 222-224, 2000.

Renaud, J., Cloke, H., and Weiler, M.: Comment on "An assessment of the tracer based approach to quantifying groundwater contributions to streamflow", edited by: Jones, J. P., Sudicky, E. A., Brookfield, A. E., and Park, Y. J., Water Resour. Res., 43(10), W02407, doi:10.1029/2006WR005157, 2007.

Rice, K. and Hornberger, G. M.: Comparison of hydrochemical tracers to estimate source contributions to peak flow in a small, forested, headwater catchment, Water Resour. Res., 34(7), 17551766, 1998.

Rockström, J., Folke, C., Gordon, L., Hatibu, N., Jewitt, G., Penning de Vries, F., Rwehumbiza, F., Sally, H., Savenije, H., and Schulze, R.: A watershed approach to upgrade rainfed agriculture in water scarce regions through Water System Innovations: an integrated research initiative on water for food and rural livelihoods in balance with ecosystem functions, Phys. Chem. Earth, 29(15-18), 1109-1118, 2004.

Rouxel, M., Molenat, J., Ruiz, L., Legout, C., Faucheux, M. and Gascuel-Odoux, C.: Seasonal and spatial variation in groundwater quality along the hillslope of an agricultural research catchment, Hydrol. Proc., 25, 831-841, 2011.

Sandström, K.: Hydrochemical deciphering of streamflow generation in semi-arid East Africa, Hydrol. Process., 10, 703-720, 1996.

Shaman, J., Stieglitz, M., and Burns, D.: Are big basins just the sum of small catchments?, Hydrol. Process., 18, 3195-3206, 2004.

Sklash, M. and Farvolden, R.: The role of groundwater in storm runoff, J. Hydrol., 3(1/4), 45-65, 1979.

Soulsby, C., Rodgers, P., Smart, R., Dawson, J., and Dunn, S.: A tracer-based assessment of hydrological pathways at different spatial scales in a mesoscale Scottish catchment, Hydrol. Process., 17, 759-777, 2003.

Soulsby, C., Tetzlaff, D., Van Den Beden, N., Malcolm, I. A., Bacon, P. J., and Youngson, A. F.: Inferring groundwater influences on surface water in montane catchments from hydrochemical surveys of springs and streamwaters, J. Hydrol., 333, 199-213, 2007. 
Soulsby, C., Tetzlaff, D., and Hrachowitz, M.: Tracers and transit times: Windows for viewing catchment scale storage? Hydrol. Process., 23, 3503-3507, 2009.

Sumner, G.: Rainfall and wind circulation in Coastal Tanzania, Meteorol. Atmos. Phys., 30(1), 107-125, 1982.

Tromp-van Meerveld, H. J. and McDonnell, J. J.: Threshold relations in subsurface stormflow 2., The fill and spill hypothesis, Water Resour. Res., 42, W02411, doi:10.1029/2004WR003800, 2006.

Uchida, T., Asano, Y., Onda, Y., and Miyata, S.: Are headwaters just the sum of hillslopes?, Hydrol. Process., 19, 3251-3261, 2005.

Uhlenbrook, S. and Hoeg, S.: Quantifying uncertainties in tracerbased hydrograph separations - A case study for two, three and five component hydrograph separations in a mountainous catchment, Hydrol. Process., 17(2), 431-453, 2003.
Uhlenbrook, S., Frey, M., Leibundgut, C., and Maloszewski, P.: Hydrograph separations in a mesoscale mountainous basin at event and seasonal timescales, Water Resour. Res., 38(6), 1-13, 2002.

Uhlenbrook, S., Didszun, J., and Wenninger, J.: Source areas and mixing of runoff components at the hillslope scale a multi-technical approach. Hydrol. Sci. J., 53(4), 741-753, doi:10.1623/hysj.53.4.741, 2008.

Weiler, M., McGlynn, B. L., McGuire, K. J., and McDonnell, J. J.: How does rainfall become runoff? A combined tracer and runoff transfer function approach, Water Resour. Res., 39, 1315-1328, 2003.

Wenninger, J., Uhlenbrook, S., Lorentz, S., and Leibundgut, C.: Identification of runoff generating processes using combined hydrometric, tracer and geophysical methods in a headwater catchment in South Africa, Hydrolog. Sci. J., 53(1), 65-80, 2008. 